\title{
Preservation and evaluation of spiced chayote juice using hurdle technology
}

\section{Preservação e avaliação de suco de chuchu com especiarias usando a tecnologia de barreiras}

\author{
Chesi Sangma1 ${ }^{1}$, Vikas Kumar ${ }^{1 *}$, Sheenam Suri ${ }^{1}$, Yogesh Gat ${ }^{1}$ (D), Manisha Kaushal ${ }^{2}$, \\ Ashwani Kumar ${ }^{1}$ (D) \\ ${ }^{1}$ Lovely Professional University (LPU), School of Agriculture, Department of Food Technology and Nutrition, \\ Phagwara/Punjab - India \\ ${ }^{2}$ Dr. Y. S. Parmar University of Horticulture and Forestry, Department of Food Science and Technology, \\ Nauni/Solan - India
}

${ }^{*}$ Corresponding Author: Vikas Kumar, Lovely Professional University (LPU), School of Agriculture, Department of Food Technology and Nutrition, Phagwara, Punjab-144411 - India, e-mail: vkchoprafst@rediffmail.com

Cite as: Sangma, C, Kumar, V, Suri, S, Gat, Y, Kaushal, M, \& Kumar, A. (2019). Preservation and evaluation of spiced chayote juice using hurdle technology. Brazilian Journal of Food Technology, 22, e2018122. https://doi.org/10.1590/1981-6723.12218

\begin{abstract}
Chayote (Sechium edule) is a perennial climbing plant, belonging to the Cucurbitaceae family and is neglected or underutilized as a food or as a raw material in the food industry because of its bland taste. This bland taste can be overcome by blending with a suitable substrate such as sugarcane juice along with natural flavouring. However, this blending represents a preservation problem for the spiced juice, since both chayote juice and sugarcane juice are prone to microbial attack. Therefore, an attempt was made in the present study to preserve the spiced chayote juice by employing different hurdles i.e. pasteurization temperature $\left(70^{\circ} \mathrm{C}\right.$ and $\left.80^{\circ} \mathrm{C}\right)$ and pasteurization time $(10$ and $20 \mathrm{~min})$ followed by the addition of different concentrations of potassium metabisulphite (KMS) (200, 300 and 400 ppm). The samples so prepared were filled into glass bottles and stored under refrigeration for forty-five days. As the storage period proceeded there were significant decreases in $\mathrm{pH}$, total protein content, total phenolic compounds, antioxidant activity, reducing power, metal chelation, tannin content, ascorbic acid content and overall acceptability, whereas there were significant increases in TSS (total soluble solids), titratable acidity, reducing sugars, total sugar, TPC (total plate count) and MIC (minimum inhibitory concentration). A cluster analysis of the data revealed that the pasteurization temperature exerted the most significant effect on the physicochemical and sensory characteristics of the spiced chayote juice as compared to the pasteurization time and KMS concentration, which failed to fall into the separate and respective clusters. In a nutshell, it was concluded that spiced chayote juice can be successfully preserved using hurdle technology (pasteurizing at $70^{\circ} \mathrm{C}$ for $10 \mathrm{~min}$ followed by the addition of 400ppm KMS).
\end{abstract}

Keywords: Chayote; Spiced chayote juice; Pasteurization temperature; Pasteurization time; KMS; Hurdle technology.

\section{Resumo}

Chuchu (Sechium edule) é uma trepadeira perene da família das Cucurbitaceae que está ignorada ou subutilizada como alimento ou como uma matéria-prima na indústria de alimentos, devido ao seu gosto brando. Este gosto brando pode ser superado fazendo misturas com um substrato apropriado, como caldo de cana e algum 
flavorizante natural. Contudo, esta mistura seria um problema para a preservação, desde que ambos - o suco de chuchu e o caldo de cana - são susceptíveis ao ataque microbiano. Portanto, neste estudo, foi feita uma tentativa de preservar o suco de chuchu com especiarias pelo emprego de diferentes barreiras, isto é, a temperatura de pasteurização $\left(70^{\circ} \mathrm{C}\right.$ e $80^{\circ} \mathrm{C}$ ) e o tempo (10 e $20 \mathrm{~min}$ ), seguidas pela adição de diferentes concentrações de metabissulfito de potássio (KMB) (200, 300 e 400 ppm). As amostras foram embaladas em vidros e armazenadas sob refrigeração para quarenta e cinco dias. Com o avanço do tempo de armazenamento, houve decréscimos significantes nos valores de $\mathrm{pH}$, proteína total, compostos fenólicos totais, atividade antioxidante, poder redutor, quelação de metais, conteúdo de taninos, ácido ascórbico e na aceitação geral, e aumentos significantes em SST (sólidos solúveis totais), acidez titulável, açúcar redutor, açúcar total, contagem total em placas (TPC) e a concentração mínima inibitória. Uma análise de cluster dos dados revelou que a temperatura de pasteurização causou o efeito mais significante nas características físico-químicas e sensoriais do suco de chuchu com especiarias, quando comparada com o tempo de pasteurização e a concentração de KMB, que deixou de cair nos clusters separados e respectivos. Foi concluído que o suco de chuchu com especiarias podia ser preservado com sucesso através da tecnologia de barreiras, com pasteurização a $70{ }^{\circ} \mathrm{C}$ por 10 min seguida pela adição de 400 ppm de KMB.

Palavras-chave: Chuchu; Suco de chuchu com especiarias; Temperatura de pasteurização; Tempo de pasteurização; KMB; Tecnologia de barreiras.

\section{Introduction}

India is well-known for its food and beverage industry which continues to expand rapidly. This growth can be attributed to changing demographics, growing disposable income, urbanization and growth of the retail industry. Freshly pressed juice provides a truly natural answer to all the requirements of a soft drink: thirst quenching, fresh, healthy, flavorsome, nutritional and, of course, natural. Juice production is only a success if it can be stored for a prolonged period without becoming spoiled. The shelf life study of food and beverages is of utmost importance from the viewpoint of industrial application. The quality of juice during and after storage depends on processing and storage procedures followed to enhance its characteristic flavor (Hussain et al., 2011).

Chayote is an underutilized vegetable belonging to the gourd family or Cucurbitaceae. The fruit is a rich source of fibre, starch, minerals and vitamins, but it has a high moisture content which reduces its shelf life and must therefore be processed for its preservation (Mishra \& Das, 2015). It is undoubtedly being used for human consumption in many countries (Hernandez-Uribe et al., 2011) as a vegetable and is consumed in many different forms (boiled, fried, steamed, stuffed, baked, salad, pickle etc). Due to its phytochemical potential, it has been reported to possess many health benefits such as the prevention of cardiovascular disease (Maity et al., 2013; Lombardo-Earl et al., 2014), chronic kidney diseases (Firdous et al., 2012; Mumtaz et al., 2012), cancer (Aguiñiga-Sánchez et al., 2015), overweight and obesity (Maity et al., 2013) and the maintenance of the blood sugar level (Maity et al., 2013) etc. Moreover, the antimicrobial activity of its juice enhances its health-related properties (Álvarez-Ordóñez et al., 2009) but it remains underutilized due to its bland taste. This problem was overcome by blending it with sugarcane juice, salt, mint and coriander extracts in an earlier attempt (Sangma et al., 2018), but the unavoidable obstacle of its preservation remained, since both chayote and sugar cane juices are prone to microbial attack and require the use of different preservation technologies such as high temperature, low temperature or chemical preservatives (Sankhla et al., 2012). However, the retention of the phytochemical potential of the juice is another great challenge and hence the use of hurdle technology is the only option to solve these problems.

Hurdle technology (combining more than one preservation approach) is a method of ensuring the elimination or control of pathogens throughout preservation (Leistner \& Gould, 2012; Sankhla et al., 2012; Rawat \& Pokhriyal, 2014). Depending on the foods, numerous hurdles have been used in the food industries to preserve foods and amongst these the most influential hurdles are low or high temperatures, modified atmosphere storage, preservatives and competitive microorganisms. These have already been used by different researchers for the preservation of different juices i.e., sugarcane, strawberry, carrot, celery and beetroot juices (Sankhla et al., 2012; Profir \& Vizireanu, 2013; Wisal et al., 2013). 
Pasteurization is a heat treatment which relies on the principle that most harmful bacteria can be killed by heat (Frazier \& Westhoff, 1988). Numerous studies have been carried out using heat treatment to improve the overall quality of various food products and increase their shelf lives. The pasteurization temperature greatly affects the sensory stability with regard to appearance, aroma, flavour and overall impression. Also, an increase in temperature results in greater stability and a gain in product shelf-life (Kunitake et al., 2014). However, it also kills virtually all of the beneficial bacteria while severely compromising the nutrient quality, leading to a "dead food" (Gao \& Rupasinghe, 2012). The complex nutrients and microscopic compounds and antioxidants responsible for much of the healing powers are destroyed or severely compromised. Chemical preservatives are used to improve the microbiological stability in beverage industries to extend the shelf-life. Sulphites i.e., sulphur-containing compounds have been used for centuries to reduce or prevent spoilage thereby enhancing the flavour and preserving the freshness of fruit juices. However, in recent years sulphites, as well as sorbates and benzoates, have been associated with allergic reactions in some people, especially in asthma sufferers (Ashurst \& Hargitt, 2009). Also, a high KMS concentration in the juice can lead to decreased acceptability of the juice as it may impart a pungent smell to the juice (Talasila et al., 2012). Thus, all the ingredients used in beverages should be used within the limits as approved by the regulatory bodies (Kregiel, 2015).

The above literature presents strong evidence to support the existence of health risks associated with the overutilization of preservatives. Also, high temperature processing for a long time can deteriorate the phytochemical potential of the juice. Moreover, it is clear from the literature that chayote is a nutritious vegetable and has a lot of medicinal value, as well as being multipurpose and high yielding, but it nevertheless remains neglected. Therefore, the present study aimed to use different hurdles with a view to this vegetable being used to produce a valuable product and hence improve its popularity as a highly nutritious vegetable worldwide.

\section{Material and method}

\subsection{Preparation and preservation of spiced chayote juice}

Raw chayote fruits were obtained from Himachal Pradesh, India and the mint, coriander and fresh sugarcane juice were obtained from the local market in Jalandhar, India. The spiced chayote juice was prepared using chayote juice $(62.5 \%)$, herbal extract $(1 \%)$, sugarcane juice $(35 \%)$ and a salt mixture $(1.5 \%)$ (Sangma et al., 2018). The beverage so prepared was filled into steam sterilized bottles and pasteurized at $70{ }^{\circ} \mathrm{C}$ and $80^{\circ} \mathrm{C}$ for 10 and 20 minutes, respectively. Different concentrations of KMS i.e., 200, 300, 400ppm, were then added to the bottles, followed by crown corking and storage under refrigeration $\left(4^{\circ} \mathrm{C}\right)$ for 45 days. Table 1 shows the details of the treatments with the different combinations of hurdles. The samples so prepared were analysed for the various physicochemical and sensory quality characteristics at 15 day intervals. In order to study the effect of multiple replicates on the quality characteristics of the spiced chayote beverage, each combination was prepared and preserved three times under the same conditions.

\subsection{Physicochemical analyses}

The total soluble solids (TSS), titratable acidity and $\mathrm{pH}$ of the blended beverages were determined as per the standard methods (Association of Official Analytical Chemistry, 1984). The reducing and total sugars were determined according to the Lane and Eynon method as described by Ranganna (1986). The total proteins were estimated using Lowry's method as described by Sadasivam \& Manickam (1992). The total phenolic compound content was determined by the modified Folin-Ciocalteau method (Sadasivam \& Manickam, 1992). The ascorbic acid content of the beverage was estimated by titration with 2,6-dichlorophenol-indophenol dye solution (Association of Official Analytical Chemistry, 1984). The free radical scavenging activity of the prepared beverages was determined by the 2, 2-diphenyl-2-picryl hydrazine (DPPH) inhibition method (Brand-Williams et al., 1995). The tannin content was determined by the Folins- Denis method (Ranganna, 1986). The reducing power of the juice was estimated using the standard procedure as described by Oyaizu (1986). The metal chelating ability of the juice was estimated by the Dinis et al. (1994) method. 


\subsection{Microbiological analyses}

\subsubsection{TPC Determination}

The total plate count was carried out using nutrient agar and potato dextrose agar, aseptically inoculating $0.1 \mathrm{~g}$ of serially diluted samples into standard plate count agar medium prepared according to Ranganna (1986). An aliquot $(0.1 \mathrm{~mL})$ of the sample after serial dilution $\left(10^{-2}, 10^{-4}, 10^{-6}\right.$ and $\left.10^{-8}\right)$ was aseptically inoculated into pre-sterilized plates followed by pouring the total plate count agar $(20-25 \mathrm{~mL})$ in a sterilize environment produced by laminar air flow. The plates were then incubated at $37^{\circ} \mathrm{C}$ for $24-48 \mathrm{~h}$ prior to counting the colonies (bacteria, yeasts and moulds). The results of the total plate count (TPC) were expressed as $\mathrm{x} 10^{6} \mathrm{CFU} / \mathrm{g}$ of sample.

\subsubsection{Determination of MIC}

The minimum inhibitory concentration (MIC) was determined by agar well diffusion. Serial dilutions of each extract $(1 \mathrm{mg} / \mathrm{ml})$ in DMSO were prepared to obtain a $0.1-0.9 \mathrm{mg} / \mathrm{ml}$ concentration range. A $100 \mu 1$ aliquot of each dilution was introduced into wells in the nutrient agar plate pre-inoculated with the test bacteria strain. The extracts were allowed to diffuse at room temperature before incubation at $37{ }^{\circ} \mathrm{C}$ for 24 hours (Jamil et al., 2012).

\subsection{Sensory analysis}

A nine-point hedonic scale was used (Amerine et al., 1965; Joshi, 2006) for the sensory evaluation of the spiced juice after the different storage intervals. Prior to the sensory analysis, the judges were familiarized with the different treatments of the spiced chayote juice and the hedonic scale in a training session. The panel of 10 semi-trained judges i.e., faculty members and post-graduate students of the Department of Food Technology and Nutrition, Lovely Professional University, was selected with care to evaluate the spiced chayote juice for its sensory parameters (colour, consistency, taste and overall acceptability). Efforts were made to maintain the same panel for the sensory evaluations throughout the entire study period. The samples were presented to the judges, and plain water also provided to rinse out their mouths between the evaluation of samples. The tests were carried out using a 9-point hedonic scale, where 9 was 'liked extremely' and 1 was 'disliked extremely'.

\subsection{Statistical analysis}

The data obtained for the physicochemical, sensory and microbiological properties of the blended chayote juice were analysed using GraphPad Prism (La Jolla, CA, USA) (version 5.01) software and the results expressed as the means \pm SEM. Differences between the means were tested for statistical significance using a 2-way ANOVA followed by the Bonferroni post hoc test. The significance level was set at $5 \%(\mathrm{P}<0.05)$ for all calculations. A cluster analysis of the data was also carried out using SPSS 16.0 software to obtain the relationship between the different treatments and the physicochemical attributes; and also a comparative comprehensive overview of the spiced chayote juice during storage.

\section{Results and discussion}

\subsection{Effect of the variables on the quality parameters}

Of all the variables under study, the TSS (total soluble solids), $\mathrm{pH}$, titratable acidity and overall acceptability were selected as the quality parameters. Due to the effects of the different treatments i.e., pasteurization temperature, time and sulphur dioxide concentration, the TSS of the spiced chayote juice varied from $9.3^{\circ} \mathrm{B}(\mathrm{T} 1)$ to $10.5^{\circ} \mathrm{B}$ (T12) on day 0 of storage (Table 1). The highest TSS for T12 might be due 
to the longer pasteurization time and higher temperature, since more heat results in more loss of water, increasing the solutes concentration and leading to the increase in TSS in T12, whereas the lowest value might be due to the shorter pasteurization time and lower temperature in T1 (Chakrabortya \& Athmaselvi, 2014). It is clearly visible from Table 1 that with the advance of the storage time, a gradual increase in TSS was observed for all treatments, which might be due to the breakdown of the polysaccharides into monosaccharides and oligosaccharides (Wisal et al., 2013), although it could also be due to the conversion of carbohydrate and acid into sugar. Kayshar et al. (2014) also reported the same changes in a mixed squash made from papaya, banana and carrot. A similar trend of a slight increase in total soluble solids with storage was also reported by Durrani et al. (2010) in apple pulp.

The titratable acidity of the spiced chayote juice varied from $0.57 \%$ (T1) to $0.99 \%$ (T3, T6 and T12) on day 0 of storage (Table 1). It was observed that with the advance of the storage time there was a gradual increase in titratable acidity, which might also have been due to the degradation of sugars into carboxyl acids, or due to the degradation of pectin into pectinic acid during storage (Riaz et al., 1989). Another explanation for the increase in acidity could be the fact that the concentration of weakly ionized acids and their salts increases during storage (Hashem et al., 2014). The $\mathrm{pH}$ of the spiced chayote juice varied from 4.60 (T12) to 4.99 (T4) on day 0 of storage (Table 1). A change in $\mathrm{pH}$ with the advance of storage can be seen in Table 1 , where the gradual decrease in $\mathrm{pH}$ might be due to the increase in acidity of the juice. These results were also in agreement with those of Kayshar et al. (2014) for a papaya, banana and carrot mixed juice. The overall acceptability of the juice varied from 6.4 (T7) to 7.5 (T1) on day 0 of storage (Table 1). The decreases in overall acceptability with the advance of storage might be due to the increase in acidity on storage, the decrease in flavour and the loss of colour of the juice during storage due to browning (Wisal et al., 2013).

Table 1. The effect of the variables on the quality parameters of the chayote blended juice after different storage periods (day 0 , day 15 , day 30 and day 45 ).

\begin{tabular}{|c|c|c|c|c|c|c|c|c|c|c|c|c|c|c|c|c|}
\hline \multirow{2}{*}{ E } & \multicolumn{4}{|c|}{ TSS $\left({ }^{\circ} \text { Brix) }\right)^{\#}$} & \multicolumn{4}{|c|}{ Titratable acidity (\%) } & \multicolumn{4}{|c|}{ pH } & \multicolumn{4}{|c|}{ Overall acceptability } \\
\hline & 0 & 15 & 30 & 45 & 0 & 15 & 30 & 45 & 0 & 15 & 30 & 45 & 0 & 15 & 30 & 45 \\
\hline $\mathrm{T} 1$ & 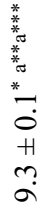 & 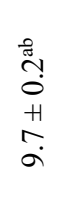 & $\begin{array}{l}\tilde{\sigma} \\
\stackrel{0}{0} \\
H \\
\infty \\
0 \\
0\end{array}$ & $\begin{array}{l}\vec{J} \\
\dot{0} \\
\dot{0} \\
H \\
0 \\
0 \\
0\end{array}$ & 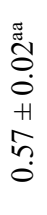 & 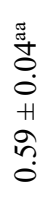 & $\begin{array}{l}\stackrel{0}{\sigma} \\
0 \\
0 \\
0 \\
H \\
0 \\
0 \\
0 \\
0\end{array}$ & 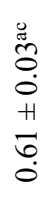 & 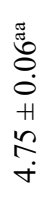 & 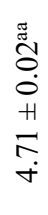 & $\begin{array}{l}\frac{\pi}{0} \\
0 \\
0 \\
0 \\
H \\
\hat{O} \\
\dot{0} \\
\dot{+}\end{array}$ & 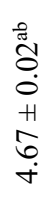 & $\begin{array}{l}\text { 芯 } \\
\\
0 \\
+1 \\
n \\
n\end{array}$ & $\begin{array}{l}\stackrel{\pi}{\pi} \\
? \\
0 \\
H \\
\text { ? } \\
?\end{array}$ & $\begin{array}{l}\stackrel{\pi}{\Xi} \\
\stackrel{0}{0} \\
H \\
-1 \\
-\end{array}$ & $\begin{array}{l}\text { ฮै } \\
\overrightarrow{0} \\
+1 \\
0 \\
0\end{array}$ \\
\hline $\mathrm{T} 2$ & $\begin{array}{l}\tilde{D} \\
\text { ? } \\
0 \\
+1 \\
n \\
a\end{array}$ & 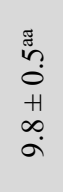 & $\begin{array}{l}\stackrel{0}{0} \\
\dot{0} \\
H \\
+1 \\
\stackrel{0}{0}\end{array}$ & $\begin{array}{l}8 \\
\text { ?n } \\
0 \\
H \\
+ \\
\dot{0}\end{array}$ & $\begin{array}{l}\tilde{\delta} \\
0 \\
0 \\
0 \\
+1 \\
\bar{\sigma} \\
0\end{array}$ & 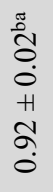 & 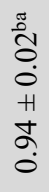 & 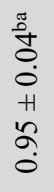 & 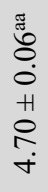 & 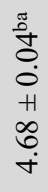 & 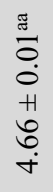 & 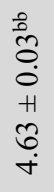 & 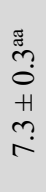 & 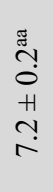 & 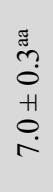 & $\begin{array}{l}\stackrel{0}{-} \\
\dot{0} \\
+ \\
\infty \\
\infty \\
0\end{array}$ \\
\hline T3 & 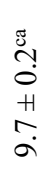 & $\begin{array}{l}\stackrel{0}{0} \\
\overrightarrow{0} \\
+1 \\
\stackrel{1}{0} \\
\stackrel{0}{0}\end{array}$ & $\begin{array}{l}8 \\
\dot{0} \\
0 \\
+1 \\
n \\
0 \\
0\end{array}$ & $\begin{array}{l}\overrightarrow{0} \\
\dot{0} \\
\dot{0} \\
\dot{H} \\
\dot{0}\end{array}$ & $\begin{array}{l}\stackrel{\Xi}{0} \\
\dot{0} \\
\dot{0} \\
+1 \\
\stackrel{\partial}{0} \\
\dot{0}\end{array}$ & 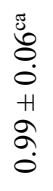 & $\begin{array}{l}\dot{0} \\
0 \\
0 \\
0 \\
H \\
\dot{0} \\
\dot{0}\end{array}$ & 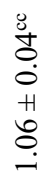 & $\begin{array}{l}\frac{\pi}{0} \\
0 \\
0 \\
0 \\
H \\
n \\
\sigma \\
\dot{\sigma}\end{array}$ & 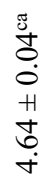 & 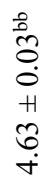 & 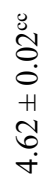 & 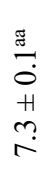 & 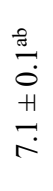 & $\begin{array}{l}\ddot{8} \\
\stackrel{+}{+} \\
0 \\
+1 \\
\sigma \\
0\end{array}$ & 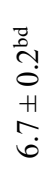 \\
\hline $\mathrm{T} 4$ & 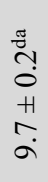 & 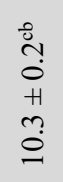 & 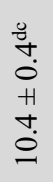 & $\begin{array}{l}\vec{g} \\
\mathfrak{m} \\
0 \\
+1 \\
0 \\
0 \\
0\end{array}$ & $\begin{array}{l}\frac{\pi}{0} \\
\stackrel{g}{0} \\
0 \\
H \\
0 \\
0 \\
0\end{array}$ & $\begin{array}{l}\tilde{\theta} \\
0 \\
0 \\
0 \\
+1 \\
\infty \\
0 \\
0\end{array}$ & 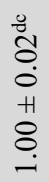 & 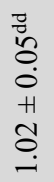 & 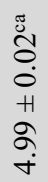 & $\begin{array}{l}\tilde{z} \\
0 \\
0 \\
0 \\
+1 \\
\bar{\sigma} \\
\dot{\nabla}\end{array}$ & $\begin{array}{l}\ddot{0} \\
0 \\
0 \\
\dot{0} \\
H \\
n \\
\infty \\
\dot{+}\end{array}$ & $\begin{array}{l}\vec{z} \\
\stackrel{0}{0} \\
0 \\
0 \\
H \\
0 \\
\infty \\
\dot{+}\end{array}$ & \begin{tabular}{l}
$\stackrel{\tilde{0}}{0}$ \\
\hdashline \\
0 \\
+ \\
$\infty$ \\
0 \\
0
\end{tabular} & 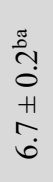 & $\begin{array}{l}0 \\
\text { in } \\
0 \\
H \\
n \\
0\end{array}$ & $\begin{array}{l}\stackrel{8}{0} \\
\dot{0} \\
+ \\
+ \\
\dot{0}\end{array}$ \\
\hline
\end{tabular}


Table 1. Continued...

\begin{tabular}{|c|c|c|c|c|c|c|c|c|c|c|c|c|c|c|c|c|}
\hline \multirow{2}{*}{ 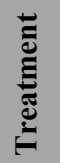 } & \multicolumn{4}{|c|}{ TSS $\left({ }^{\circ} \text { Brix }\right)^{\#}$} & \multicolumn{4}{|c|}{ Titratable acidity (\%) } & \multicolumn{4}{|c|}{$\mathbf{p H}$} & \multicolumn{4}{|c|}{ Overall acceptability } \\
\hline & $\mathbf{0}$ & 15 & 30 & 45 & $\mathbf{0}$ & 15 & 30 & 45 & $\mathbf{0}$ & 15 & 30 & 45 & $\mathbf{0}$ & 15 & 30 & 45 \\
\hline $\mathrm{T} 5$ & $\begin{array}{l}\tilde{\Xi} \\
0 \\
0 \\
+1 \\
a \\
a\end{array}$ & 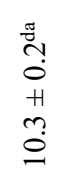 & $\begin{array}{l}\stackrel{\Xi}{5} \\
0 \\
+ \\
+1 \\
n \\
0\end{array}$ & $\begin{array}{l}\stackrel{0}{0} \\
\stackrel{0}{0} \\
+1 \\
\stackrel{0}{0}\end{array}$ & 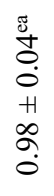 & $\begin{array}{l}\stackrel{\Xi}{5} \\
\text { Oे. } \\
0 \\
+1 \\
8 \\
8\end{array}$ & 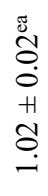 & 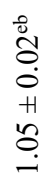 & $\begin{array}{l}\frac{\pi}{\sigma} \\
0 \\
0 \\
+ \\
+ \\
\infty \\
\dot{\sigma} \\
\dot{\sigma}\end{array}$ & $\begin{array}{l}\stackrel{\Xi}{\Xi} \\
\stackrel{0}{0} \\
\dot{0} \\
H \\
\dot{+} \\
\dot{+}\end{array}$ & $\begin{array}{l}\text { चे } \\
\dot{0} \\
0 \\
0 \\
+1 \\
0 \\
\infty \\
\dot{+}\end{array}$ & 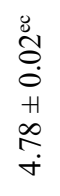 & $\begin{array}{l}\text { ָ̃ } \\
0 \\
+ \\
+1 \\
\end{array}$ & $\begin{array}{l}\stackrel{\pi}{\sigma} \\
\stackrel{0}{0} \\
+1 \\
0 \\
0\end{array}$ & $\begin{array}{l}\vec{z} \\
\overrightarrow{0} \\
+ \\
+ \\
\infty \\
0 \\
0\end{array}$ & $\begin{array}{l}\tilde{n} \\
\tilde{n} \\
0 \\
H \\
n \\
n\end{array}$ \\
\hline T6 & $\begin{array}{l}\stackrel{\Xi}{0} \\
\dot{0} \\
+1 \\
\dot{0}\end{array}$ & $\begin{array}{l}\stackrel{0}{0} \\
\stackrel{0}{0} \\
+ \\
+ \\
+ \\
0\end{array}$ & $\begin{array}{l}\stackrel{0}{0} \\
\dot{0} \\
+1 \\
\stackrel{0}{0}\end{array}$ & 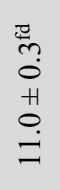 & 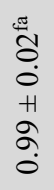 & 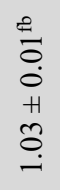 & 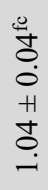 & 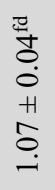 & $\begin{array}{l}\stackrel{\Xi}{5} \\
0 \\
0 \\
0 \\
H \\
0 \\
\infty \\
\dot{+}\end{array}$ & 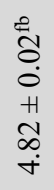 & 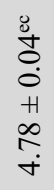 & 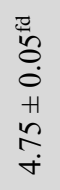 & $\begin{array}{l}\stackrel{\tilde{0}}{0} \\
0 \\
+ \\
+ \\
\infty \\
0 \\
0\end{array}$ & $\begin{array}{l}\text { in } \\
n \\
0 \\
+1 \\
n \\
n \\
0\end{array}$ & 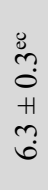 & $\begin{array}{l}\vec{J} \\
i n \\
0 \\
H \\
n \\
n \\
0\end{array}$ \\
\hline $\mathrm{T} 7$ & $\begin{array}{l}\stackrel{5}{5_{0}} \\
\overrightarrow{0} \\
+1 \\
\stackrel{+}{a} \\
a\end{array}$ & $\begin{array}{l}E \\
\stackrel{0}{0} \\
+1 \\
\\
0\end{array}$ & $\begin{array}{l}\stackrel{0}{0} \\
\stackrel{0}{0} \\
0 \\
H \\
? \\
0\end{array}$ & 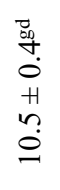 & $\begin{array}{l}\text { 品 } \\
\stackrel{0}{0} \\
0 \\
0 \\
+1 \\
\infty \\
\infty \\
0\end{array}$ & 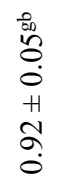 & 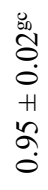 & 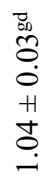 & 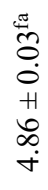 & 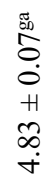 & 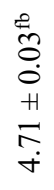 & 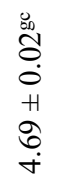 & 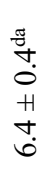 & 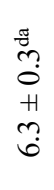 & $\begin{array}{l}\stackrel{\pi}{\uplus} \\
\dot{0} \\
+1 \\
0 \\
0 \\
0\end{array}$ & 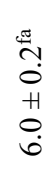 \\
\hline $\mathrm{T} 8$ & 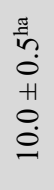 & 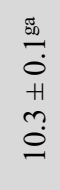 & 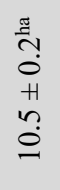 & 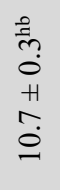 & 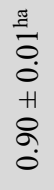 & 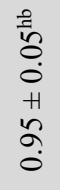 & $\begin{array}{l}0 \\
\tilde{0} \\
0 \\
0 \\
H \\
\hat{0} \\
\vdots\end{array}$ & 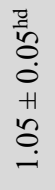 & $\begin{array}{l}\stackrel{5}{5} \\
2 \\
0 \\
0 \\
H \\
H \\
\infty \\
\dot{+}\end{array}$ & 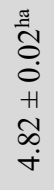 & $\begin{array}{l}\stackrel{0}{0} \\
\text { on } \\
0 \\
0 \\
+ \\
+ \\
\infty \\
\dot{+}\end{array}$ & 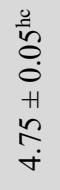 & $\begin{array}{l}\stackrel{\Xi}{\Delta} \\
\stackrel{0}{0} \\
+ \\
\forall \\
\forall\end{array}$ & 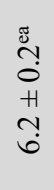 & 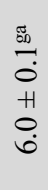 & 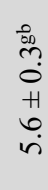 \\
\hline T9 & 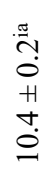 & $\begin{array}{l}\underbrace{\circ}_{0} \\
0 \\
0 \\
+1 \\
0 \\
0 \\
0\end{array}$ & $\begin{array}{l}\stackrel{0}{m} \\
0 \\
+1 \\
\infty \\
0 \\
0\end{array}$ & $\begin{array}{l}\stackrel{0}{n} \\
\vdots \\
+1 \\
0 \\
\stackrel{\Xi}{=}\end{array}$ & 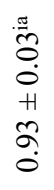 & 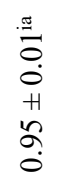 & $\begin{array}{l}\cong \\
0 \\
0 \\
+ \\
+1 \\
\infty \\
0 \\
0\end{array}$ & $\begin{array}{l}\stackrel{0}{0} \\
0 \\
0 \\
+1 \\
0 \\
0\end{array}$ & 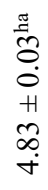 & 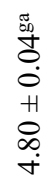 & $\begin{array}{l}\stackrel{0}{\tilde{\sigma}} \\
\tilde{0} \\
0 \\
+ \\
+ \\
\infty \\
0 \\
\dot{+}\end{array}$ & $\begin{array}{l}\stackrel{0}{\sigma} \\
0 \\
0 \\
0 \\
H \\
0 \\
0 \\
\dot{\sigma}\end{array}$ & 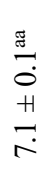 & 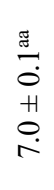 & $\begin{array}{l}\stackrel{0}{\sigma} \\
\overrightarrow{0} \\
+ \\
+ \\
\infty \\
0\end{array}$ & $\begin{array}{l}\stackrel{8}{0} \\
\dot{0} \\
H \\
\text { in }\end{array}$ \\
\hline $\mathrm{T} 10$ & 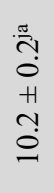 & $\begin{array}{l}\text { Ñ } \\
0 \\
+1 \\
n \\
0\end{array}$ & $\begin{array}{l}\stackrel{0}{O} \\
0 \\
H \\
+1 \\
0 \\
0\end{array}$ & 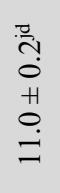 & 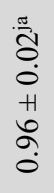 & 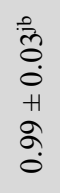 & $\begin{array}{l}0 \\
0 \\
0 \\
+ \\
+ \\
\tilde{0} \\
0\end{array}$ & 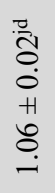 & 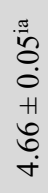 & 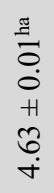 & $\begin{array}{l}\stackrel{0}{0} \\
0 \\
0 \\
0 \\
+ \\
\infty \\
\infty \\
\dot{+}\end{array}$ & 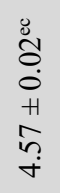 & $\begin{array}{l}\widetilde{\Xi} \\
\dot{0} \\
+ \\
o \\
\dot{0}\end{array}$ & 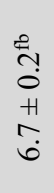 & $\begin{array}{l}0 \\
\ddot{n} \\
0 \\
+1 \\
n \\
n\end{array}$ & $\begin{array}{l}\vec{z} \\
n \\
0 \\
H \\
n \\
n \\
n\end{array}$ \\
\hline T11 & 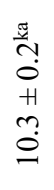 & 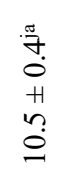 & $\begin{array}{l}\stackrel{\vec{n}}{m} \\
0 \\
+ \\
\infty \\
0 \\
0\end{array}$ & 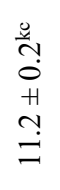 & 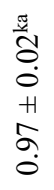 & $\begin{array}{l}\stackrel{\Xi}{0} \\
0 \\
0 \\
+ \\
+1 \\
\infty \\
0 \\
0\end{array}$ & 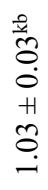 & 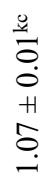 & 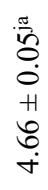 & 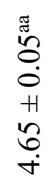 & $\begin{array}{l}\tilde{\Xi} \\
\tilde{\sigma} \\
0 \\
0 \\
+ \\
\hat{b} \\
\dot{\forall}\end{array}$ & 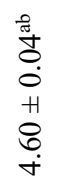 & 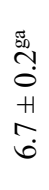 & 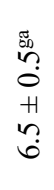 & $\begin{array}{l}0 \\
00 \\
n \\
0 \\
+1 \\
n \\
n\end{array}$ & 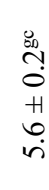 \\
\hline $\mathrm{T} 12$ & $\begin{array}{l}\frac{\pi}{n} \\
0 \\
+1 \\
n \\
0 \\
0\end{array}$ & $\begin{array}{l}\text { 寽 } \\
0 \\
0 \\
+1 \\
0 \\
0 \\
0\end{array}$ & 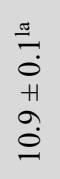 & $\begin{array}{l}\stackrel{0}{m} \\
0 \\
H \\
m \\
=\end{array}$ & 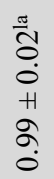 & $\begin{array}{l}\stackrel{0}{0} \\
\text { ọ } \\
0 \\
\text { H } \\
\text { ô }\end{array}$ & $\begin{array}{l}\frac{0}{12} \\
0 \\
0 \\
H \\
n \\
0 \\
-\end{array}$ & 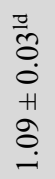 & 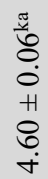 & 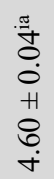 & 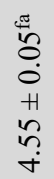 & 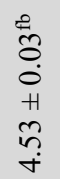 & 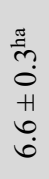 & 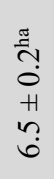 & 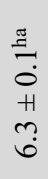 & $\begin{array}{l}\stackrel{0}{1} \\
\text { o } \\
\text { H } \\
b \\
\dot{n}\end{array}$ \\
\hline
\end{tabular}

*Mean \pm SD $(\mathrm{n}=3)$; \#Total soluble solids; **Different superscripts in the same column indicate a significant difference $(\mathrm{p}<0.05)$; *** Different superscripts in the same row indicate a significant difference $(\mathrm{p}<0.05) . \mathrm{T} 1: 70{ }^{\circ} \mathrm{C}, 10 \mathrm{~min}, 200 \mathrm{ppm} ; \mathrm{T} 2: 70{ }^{\circ} \mathrm{C}, 10 \mathrm{~min}, 300 \mathrm{ppm}$; $\mathrm{T} 3: 70{ }^{\circ} \mathrm{C}, 10 \mathrm{~min}, 400 \mathrm{ppm} ; \mathrm{T} 4: 70{ }^{\circ} \mathrm{C}, 20 \mathrm{~min}, 200 \mathrm{ppm}$; T5:70 ${ }^{\circ} \mathrm{C}, 20 \mathrm{~min}, 300 \mathrm{ppm}$; T6:70 ${ }^{\circ} \mathrm{C}, 20 \mathrm{~min}, 400 \mathrm{ppm} ; \mathrm{T} 7: 80^{\circ} \mathrm{C}, 10 \mathrm{~min}, 200 \mathrm{ppm}$; $\mathrm{T} 8: 80^{\circ} \mathrm{C}, 10 \mathrm{~min}, 300 \mathrm{ppm} ; \mathrm{T} 9: 80^{\circ} \mathrm{C}, 10 \mathrm{~min}, 400 \mathrm{ppm} ; \mathrm{T} 10: 80^{\circ} \mathrm{C}, 20 \mathrm{~min}, 200 \mathrm{ppm} ; \mathrm{T} 11: 80{ }^{\circ} \mathrm{C}, 20 \mathrm{~min}, 300 \mathrm{ppm} ; \mathrm{T} 12: 80^{\circ} \mathrm{C}, 20 \mathrm{~min}, 400 \mathrm{ppm}$.

\subsection{Effect of the variables on the nutritional parameters}

Of all the variables under study the reducing sugar, total sugar, total protein and ascorbic acid contents were taken as the nutritional parameters. Due to the effects of the different treatments i.e., pasteurization 
temperature, pasteurization time and sulphur dioxide concentration, the reducing sugar content of the juice varied from $0.752 \%$ (T1) to $0.586 \%$ (T12) on day 0 of storage (Table 2). The results show a significant increase in reducing sugar content with increase in storage period (Table 2) probably due primarily to the conversion of sucrose into reducing sugars by acids and the hydrolysis of polysaccharides into simple sugars (glucose and fructose) (Wisal et al., 2013). The total sugar content of the spiced chayote juice varied from $6.54 \%$ (T12) to $7.05 \%$ (T1) on day 0 of storage (Table 2). With the advance of storage, there was an increase in total sugar content for all treatments, which might be due to the degradation of complex polysaccharides such as pectin into simple sugars. Similar results were reported by Madan \& Dhawan (2005) and Lanjhiyana et al. (2010) for carrot juice and a lime - ginger blended squash, respectively.

The total protein content of the spiced chayote juice varied from $138.06 \mathrm{mg} / 100 \mathrm{~mL}$ (T1) to $162.00 \mathrm{mg} / 100 \mathrm{ml}$ (T12) on day 0 of storage (Table 2). It was observed that with the advance of storage, a decrease in total protein was observed for all treatments, which might be due to the involvement of nonenzymatic browning by way of the interaction with organic acids and sugar (Pareek et al., 2015). The ascorbic acid content of the spiced chayote juice varied from $7.55 \mathrm{mg} / 100 \mathrm{~mL}$ (T10) to $9.32 \mathrm{mg} / 100 \mathrm{~mL}$ (T3) on day 0 of storage (Table 2) and decreased significantly during storage, which might be due to oxidation by residual oxygen, followed by decomposition, which might have accelerated with storage time. These findings are in agreement with the studies of Ibrahim (2016).

Table 2. The effect of the variables on the nutritional parameters of the blended chayote juice after different storage periods.

\begin{tabular}{|c|c|c|c|c|c|c|c|c|c|c|c|c|c|c|c|c|}
\hline \multirow{2}{*}{ 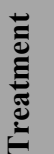 } & \multicolumn{4}{|c|}{ Reducing sugar (\%) } & \multicolumn{4}{|c|}{ Total sugar (\%) } & \multicolumn{4}{|c|}{ Total protein $(\mathrm{mg} / \mathbf{1 0 0} \mathrm{ml})$} & \multicolumn{4}{|c|}{ Ascorbic acid (mg/100ml) } \\
\hline & $\mathbf{0}$ & 15 & 30 & 45 & $\mathbf{0}$ & 15 & 30 & 45 & $\mathbf{0}$ & 15 & 30 & 45 & $\mathbf{0}$ & 15 & 30 & 45 \\
\hline
\end{tabular}

$\mathrm{T} 1$

\begin{tabular}{|c|c|c|c|c|c|c|}
\hline 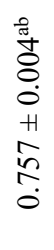 & 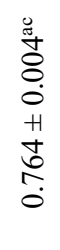 & 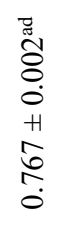 & 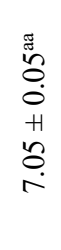 & 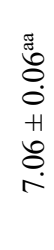 & 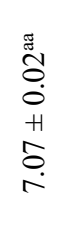 & $\begin{array}{l}\tilde{\sigma} \\
0 \\
0 \\
0 \\
+ \\
\infty \\
0 \\
0\end{array}$ \\
\hline
\end{tabular}

\begin{tabular}{|c|c|c|c|c|c|c|c|c|c|c|c|c|c|c|c|c|}
\hline $\mathrm{T} 2$ & 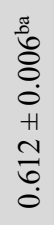 & 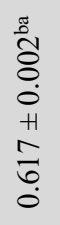 & 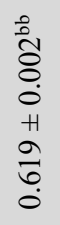 & 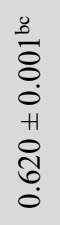 & 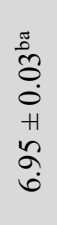 & 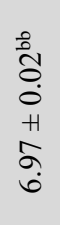 & 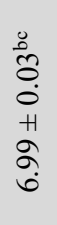 & 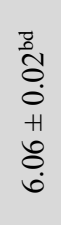 & 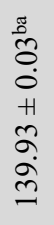 & 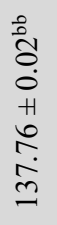 & 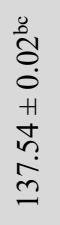 & $\begin{array}{l}\tilde{J} \\
0 \\
0 \\
0 \\
+1 \\
\infty \\
0 \\
0 \\
0 \\
0 \\
0\end{array}$ & 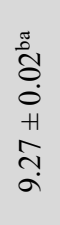 & 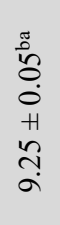 & 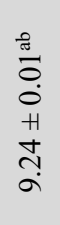 & 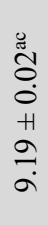 \\
\hline $\mathrm{T} 3$ & 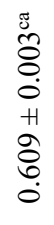 & 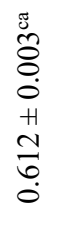 & 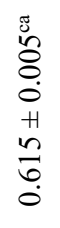 & $\begin{array}{l}\dot{0} \\
\dot{0} \\
\dot{0} \\
\dot{0} \\
+1 \\
0 \\
\dot{0} \\
\dot{0}\end{array}$ & 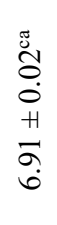 & 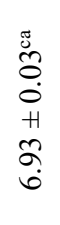 & 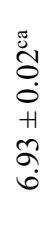 & $\begin{array}{l}0 \\
\ddot{0} \\
0 \\
0 \\
+1 \\
\circ \\
0 \\
0\end{array}$ & 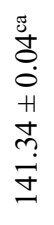 & 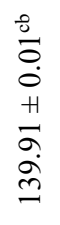 & 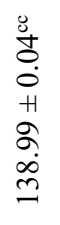 & 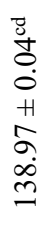 & $\begin{array}{l}\tilde{0} \\
0 \\
0 \\
0 \\
H \\
\tilde{\sigma} \\
\tilde{\sigma}\end{array}$ & $\begin{array}{l}0 \\
0 \\
0 \\
0 \\
+ \\
+1 \\
\infty \\
\\
a\end{array}$ & 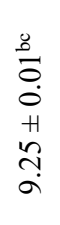 & 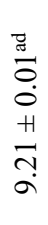 \\
\hline $\mathrm{T} 4$ & 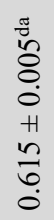 & $\begin{array}{l}\tilde{\sigma} \\
\tilde{\delta} \\
0 \\
0 \\
H \\
\infty \\
0 \\
0 \\
0\end{array}$ & 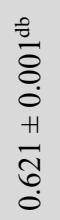 & $\begin{array}{l}\tilde{0} \\
\tilde{\delta} \\
0 \\
0 \\
H \\
\tilde{\triangleq} \\
0 \\
0\end{array}$ & 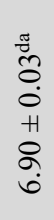 & 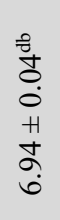 & 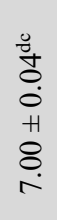 & 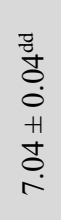 & 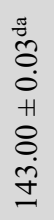 & 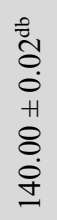 & 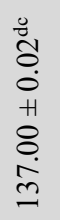 & $\begin{array}{l}\vec{z} \\
\ddot{i} \\
0 \\
0 \\
+1 \\
8 \\
8 \\
\dot{n} \\
m\end{array}$ & $\begin{array}{l}\frac{\pi}{\sigma} \\
\dot{\sigma} \\
\dot{0} \\
H \\
\stackrel{H}{\infty} \\
\infty\end{array}$ & $\begin{array}{l}\frac{\pi}{\tilde{J}} \\
\dot{\sigma} \\
0 \\
+ \\
H \\
i \\
\infty \\
\infty\end{array}$ & $\begin{array}{l}\stackrel{\Xi}{5} \\
\stackrel{0}{0} \\
0 \\
+ \\
+ \\
\stackrel{1}{0} \\
\infty\end{array}$ & 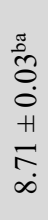 \\
\hline
\end{tabular}


Table 2. Continued...

\begin{tabular}{|c|c|c|c|c|c|c|c|c|c|c|c|c|c|c|c|c|}
\hline \multirow{2}{*}{ 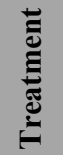 } & \multicolumn{4}{|c|}{ Reducing sugar (\%) } & \multicolumn{4}{|c|}{ Total sugar (\%) } & \multicolumn{4}{|c|}{ Total protein $(\mathrm{mg} / \mathbf{1 0 0 m l})$} & \multicolumn{4}{|c|}{ Ascorbic acid (mg/100ml) } \\
\hline & $\mathbf{0}$ & 15 & 30 & 45 & $\mathbf{0}$ & 15 & 30 & 45 & $\mathbf{0}$ & 15 & 30 & 45 & $\mathbf{0}$ & 15 & 30 & 45 \\
\hline T5 & 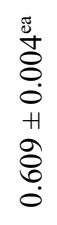 & $\begin{array}{l}\tilde{J} \\
\tilde{O} \\
0 \\
0 \\
H \\
\tilde{n} \\
\ddot{0} \\
\dot{0}\end{array}$ & $\begin{array}{l}\text { ه̊ } \\
\overparen{8} \\
0 \\
0 \\
+1 \\
0 \\
0 \\
0 \\
0\end{array}$ & 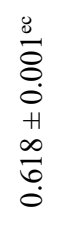 & 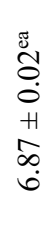 & 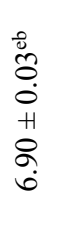 & 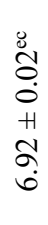 & 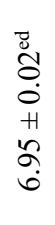 & 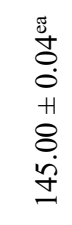 & 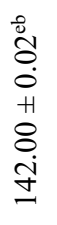 & 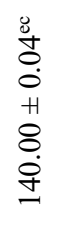 & 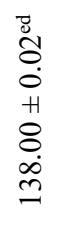 & $\begin{array}{l}\tilde{J} \\
0 \\
0 \\
0 \\
+1 \\
o \\
\infty \\
\infty\end{array}$ & $\begin{array}{l}\stackrel{0}{0} \\
\stackrel{0}{0} \\
0 \\
+ \\
+1 \\
\stackrel{0}{0} \\
\stackrel{\infty}{\infty}\end{array}$ & $\begin{array}{l}0 \\
0 \\
0 \\
0 \\
+ \\
H \\
+ \\
\dot{\infty}\end{array}$ & $\begin{array}{l}\vec{z} \\
\stackrel{0}{0} \\
\dot{0} \\
H \\
\stackrel{H}{N} \\
\infty \\
\infty\end{array}$ \\
\hline T6 & $\begin{array}{l}\stackrel{\Xi}{\pi} \\
8 \\
0 \\
0 \\
+1 \\
0 \\
0 \\
0 \\
0\end{array}$ & 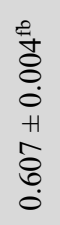 & $\begin{array}{l}0 \\
\hat{\delta} \\
0 \\
0 \\
+1 \\
0 \\
0 \\
0 \\
0\end{array}$ & $\begin{array}{l}\vec{D} \\
\tilde{\delta} \\
\dot{\delta} \\
\dot{0} \\
H \\
m \\
\tilde{n} \\
\dot{0}\end{array}$ & $\begin{array}{l}\text { 焉 } \\
0 \\
0 \\
+ \\
H \\
0 \\
0 \\
0 \\
0\end{array}$ & 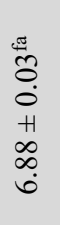 & $\begin{array}{l}\stackrel{0}{0} \\
0 \\
0 \\
+ \\
+ \\
\sigma \\
\sigma\end{array}$ & 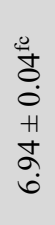 & 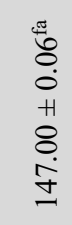 & 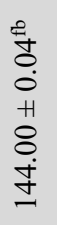 & 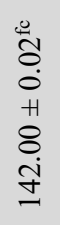 & $\begin{array}{l}\vec{Z} \\
\dot{0} \\
\dot{0} \\
+ \\
8 \\
8 \\
\dot{+}\end{array}$ & 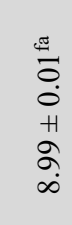 & $\begin{array}{l}E \\
\dot{E} \\
0 \\
0 \\
H \\
+ \\
0 \\
0 \\
\infty\end{array}$ & $\begin{array}{l}\ddot{8} \\
\stackrel{0}{0} \\
0 \\
+ \\
H \\
\widehat{b} \\
\infty \\
\infty\end{array}$ & 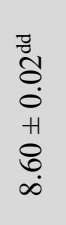 \\
\hline $\mathrm{T} 7$ & 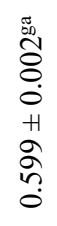 & 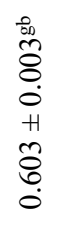 & 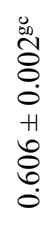 & 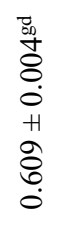 & 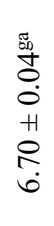 & 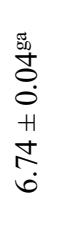 & $\begin{array}{l}\stackrel{0}{0} \\
0 \\
0 \\
0 \\
+1 \\
\infty \\
0 \\
0\end{array}$ & $\begin{array}{l}0 \\
8 \\
0 \\
0 \\
0 \\
H \\
0 \\
0 \\
0 \\
0\end{array}$ & 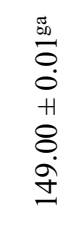 & $\begin{array}{l}\text { on } \\
\text { Oे } \\
0 \\
0 \\
+1 \\
8 \\
8 \\
\dot{0} \\
\dot{0}\end{array}$ & 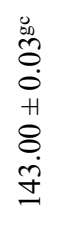 & $\begin{array}{l}\vec{b} \\
0 \\
0 \\
0 \\
+1 \\
8 \\
8 \\
\dot{0} \\
\pm\end{array}$ & $\begin{array}{l}{ }_{0}^{5} \\
0 \\
0 \\
0 \\
0 \\
+ \\
+0 \\
0 \\
\infty\end{array}$ & 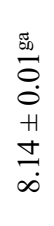 & 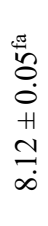 & $\begin{array}{l}\stackrel{0}{0} \\
\stackrel{0}{0} \\
0 \\
+1 \\
+1 \\
\dot{0} \\
\infty\end{array}$ \\
\hline $\mathrm{T} 8$ & 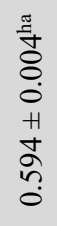 & 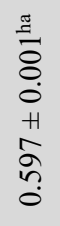 & 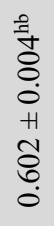 & 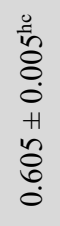 & 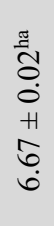 & 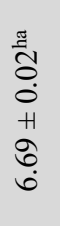 & 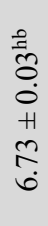 & $\begin{array}{l}0 \\
\stackrel{0}{0} \\
0 \\
+1 \\
0 \\
0 \\
0\end{array}$ & 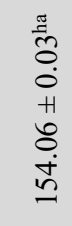 & 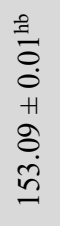 & 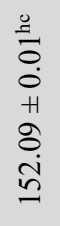 & 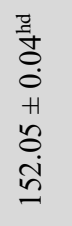 & $\begin{array}{l}\tilde{\pi} \\
\widetilde{\sigma} \\
0 \\
+ \\
+ \\
\tilde{N} \\
\infty\end{array}$ & 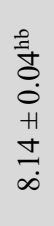 & $\begin{array}{l}\stackrel{0}{\circ} \\
\stackrel{0}{0} \\
0 \\
0 \\
H \\
= \\
= \\
\infty\end{array}$ & 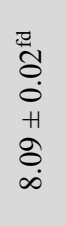 \\
\hline T9 & 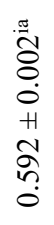 & 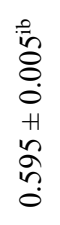 & $\begin{array}{l}.0 \\
0 \\
8 \\
0 \\
+1 \\
\infty \\
\infty \\
0 \\
0 \\
0\end{array}$ & 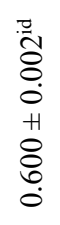 & 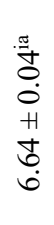 & 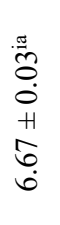 & $\begin{array}{l}0 \\
0 \\
0 \\
0 \\
H \\
\stackrel{H}{0} \\
0\end{array}$ & 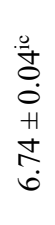 & 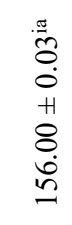 & 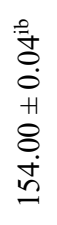 & 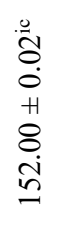 & 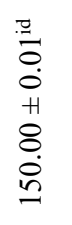 & 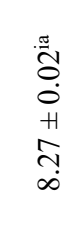 & 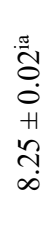 & 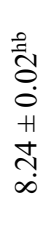 & 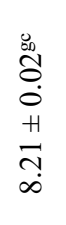 \\
\hline $\mathrm{T} 10$ & $\begin{array}{l}\frac{a}{2} \\
\overline{8} \\
0 \\
+1 \\
+1 \\
\tilde{\sigma} \\
0\end{array}$ & 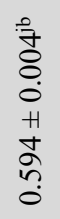 & 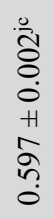 & 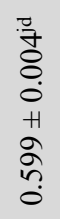 & $\begin{array}{l}\stackrel{\sigma}{0} \\
0 \\
0 \\
+1 \\
0 \\
0 \\
0 \\
0\end{array}$ & 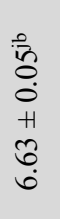 & $\begin{array}{l}0 \\
\tilde{\sigma} \\
0 \\
0 \\
H \\
0 \\
0 \\
0\end{array}$ & 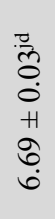 & 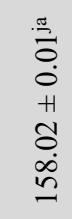 & $\begin{array}{l}0 \\
\text { है } \\
0 \\
0 \\
+1 \\
8 \\
8 \\
i n \\
n\end{array}$ & $\begin{array}{l}\frac{0}{\tilde{m}} \\
0 \\
0 \\
+1 \\
8 \\
\dot{8} \\
\tilde{n}\end{array}$ & 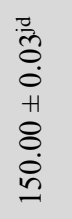 & 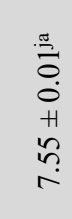 & 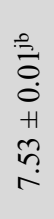 & 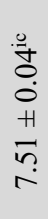 & 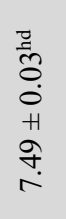 \\
\hline $\mathrm{T} 11$ & 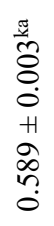 & 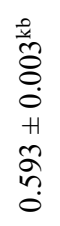 & $\begin{array}{l}\frac{8}{*} \\
\hat{\delta} \\
0 \\
0 \\
+1 \\
0 \\
0 \\
0 \\
0\end{array}$ & $\begin{array}{l}\vec{z} \\
\tilde{\delta} \\
0 \\
0 \\
+1 \\
8 \\
8 \\
0 \\
0\end{array}$ & 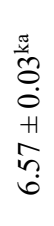 & 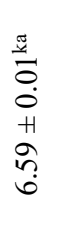 & 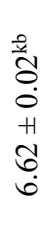 & 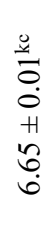 & 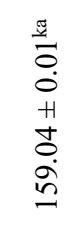 & 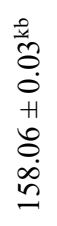 & 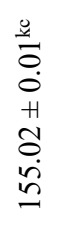 & 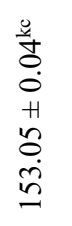 & 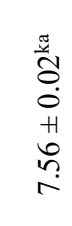 & 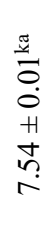 & $\begin{array}{l}\stackrel{0}{0} \\
0 \\
0 \\
+ \\
N \\
\sim \\
N\end{array}$ & 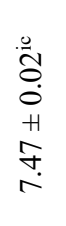 \\
\hline $\mathrm{T} 12$ & 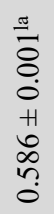 & 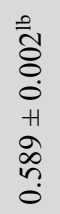 & 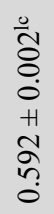 & 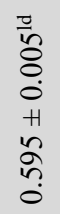 & $\begin{array}{l}\frac{\pi}{\Delta} \\
0 \\
0 \\
H \\
\dot{H} \\
\dot{n} \\
0\end{array}$ & $\begin{array}{l}\frac{\pi}{3} \\
0 \\
0 \\
+1 \\
0 \\
n \\
0\end{array}$ & 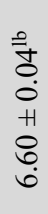 & 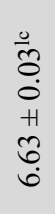 & 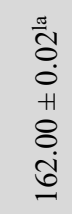 & $\begin{array}{l}\stackrel{0}{ \pm} \\
\stackrel{0}{0} \\
+1 \\
8 \\
8 \\
\dot{8}\end{array}$ & $\begin{array}{l}\stackrel{0}{J} \\
0 \\
0 \\
+ \\
+ \\
8 \\
\infty \\
\infty \\
0\end{array}$ & 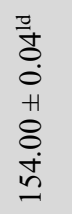 & $\begin{array}{l}\frac{\pi}{0} \\
0 \\
0 \\
+1 \\
0 \\
0 \\
0\end{array}$ & 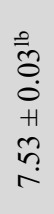 & 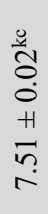 & 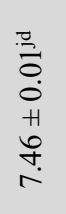 \\
\hline
\end{tabular}

*Mean $\pm \mathrm{SD}(\mathrm{n}=3)$; **Different superscripts in the same column indicate a significant difference $(\mathrm{p}<0.05)$; ***Different superscripts in the same row indicate a significant difference $(\mathrm{p}<0.05)$. T1:70 ${ }^{\circ} \mathrm{C}, 10 \mathrm{~min}, 200 \mathrm{ppm} ; \mathrm{T} 2: 70{ }^{\circ} \mathrm{C}, 10 \mathrm{~min}, 300 \mathrm{ppm} ; \mathrm{T} 3: 70{ }^{\circ} \mathrm{C}, 10 \mathrm{~min}, 400 \mathrm{ppm}$; $\mathrm{T} 4: 70{ }^{\circ} \mathrm{C}, 20 \mathrm{~min}, 200 \mathrm{ppm} ; \mathrm{T} 5: 70{ }^{\circ} \mathrm{C}, 20 \mathrm{~min}, 300 \mathrm{ppm} ; \mathrm{T} 6: 70{ }^{\circ} \mathrm{C}, 20 \mathrm{~min}, 400 \mathrm{ppm} ; \mathrm{T} 7: 80{ }^{\circ} \mathrm{C}, 10 \mathrm{~min}, 200 \mathrm{ppm} ; \mathrm{T} 8: 80{ }^{\circ} \mathrm{C}, 10 \mathrm{~min}, 300 \mathrm{ppm}$; $\mathrm{T} 9: 80^{\circ} \mathrm{C}, 10 \mathrm{~min}, 400 \mathrm{ppm} ; \mathrm{T} 10: 80{ }^{\circ} \mathrm{C}, 20 \mathrm{~min}, 200 \mathrm{ppm} ; \mathrm{T} 11: 80{ }^{\circ} \mathrm{C}, 20 \mathrm{~min}, 300 \mathrm{ppm} ; \mathrm{T} 12: 80{ }^{\circ} \mathrm{C}, 20 \mathrm{~min}, 400 \mathrm{ppm}$. 


\subsection{Effect of the variables on the phytochemical attributes}

Of all the variables under study, the total phenolic compound, antioxidant, reducing power, metal chelation and tannin contents were selected as the phytochemical attributes. Due to the effect of the different treatments i.e., pasteurization temperature, pasteurization time and sulphur dioxide concentration, the total phenolic compound content of the spiced chayote juice varied from $27.24 \mathrm{mg} / 100 \mathrm{ml}$ (T1) to $32.91 \mathrm{mg} / 100 \mathrm{~mL}$ (T12) on day 0 of storage (Table 3). The data revealed that with the advance of storage, there was a decrease in the total phenolic compound content for all treatments, which might be due to the decrease in some individual polyphenolic compounds since they are water soluble compounds and sensitive to oxidation, which results in their degradation during storage (Bhattacherjee et al., 2011).The decrease in the total phenolic compound content might also be due to the transformation of some monomeric anthocyanins into polymeric compounds (Mgaya-Kilima et al., 2014). The antioxidant activity of the spiced chayote juice varied from $60.66 \%$ (T1) to $66.49 \%$ (T12) on day 0 of storage (Table 3 ). A decline in antioxidant activity was observed for all treatments with the advance of storage, which might be due to the loss of ascorbic acid and total phenolic compounds due to oxidation and other reactions (Kapasakalidis et al., 2006; Oszmianski \& Wojdylo, 2009). The decrease in antioxidant activity may be linked to lower phenolic compound and ascorbic acid contents in the stored juice as compared to the fresh juice (Hashem et al., 2014). The tannin content of the juice varied from $0.50 \mathrm{mg} / 100 \mathrm{~mL}$ (T12) to $0.64 \mathrm{mg} / 100 \mathrm{~mL}$ (T3) on day 0 of storage (Table 3) and with the passage of storage time, a decrease in tannin content was observed. Similar results were reported by Talasila et al. (2012) for cashew apple juice, who suggested that the decrease in tannin content was due to the addition of metabisulphite, which prevents browning of the juice. The reducing power and metal chelation of the spiced chayote juice varied from $58.0 \%$ (T10) to $59.9 \%$ (T3) and from $65.07 \%$ (T1) to $69.09 \%$ (T11 and T12), respectively, on day 0 of storage (Table 3). The decrease in reducing power and metal chelation of the juice during storage might be due to the decreases in ascorbic acid and phenolic compound contents of the juice, as discussed earlier.

Table 3. The effects of the variables on the phytochemical attributes of the blended chayote juice after different storage periods.

\begin{tabular}{|c|c|c|c|c|c|c|c|c|c|c|c|c|c|c|c|c|c|c|c|c|}
\hline \multirow{2}{*}{ 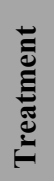 } & \multicolumn{4}{|c|}{$\begin{array}{c}\text { Total phenolic } \\
\text { compounds } \\
\text { (mg/100ml) }\end{array}$} & \multicolumn{4}{|c|}{$\begin{array}{c}\text { Antioxidant activity } \\
(\%)\end{array}$} & \multicolumn{4}{|c|}{$\begin{array}{l}\text { Tannin content } \\
(\mathrm{mg} / \mathbf{1 0 0 m l})\end{array}$} & \multicolumn{4}{|c|}{ Reducing power (\%) } & \multicolumn{4}{|c|}{ Metal chelation (\%) } \\
\hline & $\mathbf{0}$ & 15 & 30 & 45 & $\mathbf{0}$ & 15 & 30 & 45 & $\mathbf{0}$ & 15 & 30 & 45 & $\mathbf{0}$ & 15 & 30 & 45 & $\mathbf{0}$ & 15 & 30 & 45 \\
\hline
\end{tabular}

$\mathrm{T} 1$

\begin{tabular}{|c|c|c|c|c|c|c|c|}
\hline 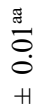 & $\begin{array}{l}\tilde{\tilde{\sigma}} \\
\stackrel{8}{0} \\
+ \\
+\end{array}$ & 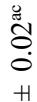 & $\begin{array}{l}\stackrel{g}{\mathscr{g}} \mathrm{O} \\
\stackrel{0}{0} \\
\dot{H}\end{array}$ & 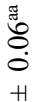 & 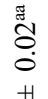 & 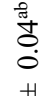 & $\stackrel{\frac{\pi}{\sigma}}{0}$ \\
\hline$\tilde{\lambda}$ & $\nabla$ & o & 8 & $\sigma$ & in & n & + \\
\hline$\grave{\sim}$ & $\dot{\sim}$ & i & 8 & 8 & 8 & 8 & $\tilde{c}$ \\
\hline
\end{tabular}

\begin{tabular}{|c|c|c|c|c|c|c|c|c|c|c|c|c|c|c|c|c|c|c|c|c|}
\hline $\mathrm{T} 2$ & 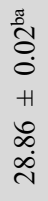 & 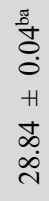 & $\begin{array}{l}\stackrel{\pi}{0} \\
\stackrel{0}{0} \\
0 \\
H \\
\infty \\
\infty \\
\infty \\
\infty\end{array}$ & 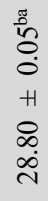 & 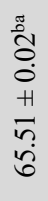 & 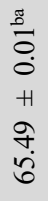 & 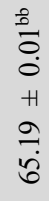 & $\begin{array}{l}0 \\
0 \\
0 \\
0 \\
H \\
\text { H } \\
o \\
\dot{0}\end{array}$ & 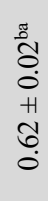 & 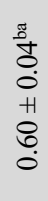 & 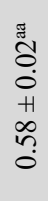 & 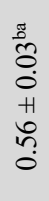 & 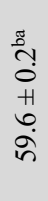 & $\begin{array}{l}\text { ô } \\
\text { ?o } \\
\text { H } \\
\text { ma } \\
\text { nn }\end{array}$ & 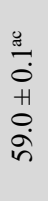 & $\begin{array}{l}\tilde{J} \\
\tilde{n} \\
0 \\
H \\
\infty \\
\infty \\
\infty \\
\infty\end{array}$ & 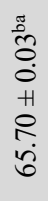 & $\begin{array}{l}\stackrel{0}{0} \\
\text { ô } \\
\dot{0} \\
+1 \\
\text { ? } \\
\dot{0}\end{array}$ & 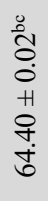 & 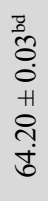 \\
\hline $\mathrm{T} 3$ & 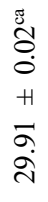 & 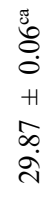 & 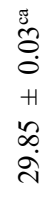 & 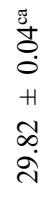 & 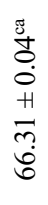 & 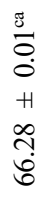 & 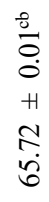 & $\begin{array}{l}8 \\
\tilde{O} \\
\dot{0} \\
H \\
\tilde{\sigma} \\
\tilde{\sigma} \\
\ddot{0}\end{array}$ & 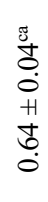 & $\begin{array}{l}\frac{\pi}{0} \\
0 \\
0 \\
+ \\
+ \\
0 \\
0\end{array}$ & $\begin{array}{l}\stackrel{\tilde{n}}{\tilde{O}} \\
0 \\
0 \\
+1 \\
\tilde{o} \\
\tilde{0}\end{array}$ & 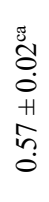 & 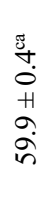 & 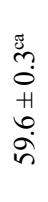 & 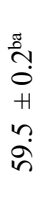 & $\begin{array}{l}0 \\
0 \\
0 \\
+1 \\
0 \\
0\end{array}$ & 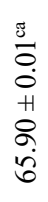 & $\begin{array}{l}0 \\
\tilde{c} \\
0 \\
\dot{0} \\
+1 \\
0 \\
0 \\
\dot{0}\end{array}$ & $\begin{array}{l}8 \\
\stackrel{0}{0} \\
\dot{0} \\
H \\
\dot{H} \\
\dot{0}\end{array}$ & $\begin{array}{l}\tilde{0} \\
0 \\
0 \\
+ \\
+1 \\
8 \\
0 \\
\dot{0}\end{array}$ \\
\hline T4 & 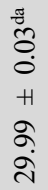 & 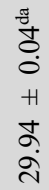 & 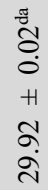 & 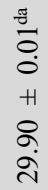 & 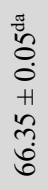 & 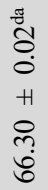 & 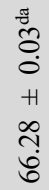 & 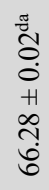 & 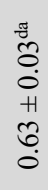 & $\begin{array}{l}\frac{\pi}{0} \\
\dot{0} \\
\dot{0} \\
+1 \\
0 \\
0 \\
0\end{array}$ & 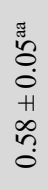 & 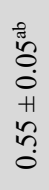 & $\begin{array}{l}\frac{\pi}{0} \\
\overrightarrow{0} \\
+ \\
\tilde{n} \\
\tilde{n}\end{array}$ & $\begin{array}{l}\text { ज्ञ } \\
0 \\
+1 \\
0 \\
\dot{n}\end{array}$ & $\begin{array}{l}\text { ¿ू. } \\
0 \\
\text { H } \\
r\end{array}$ & 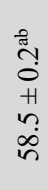 & 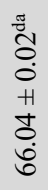 & 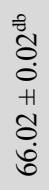 & $\begin{array}{l}\frac{0}{ \pm} \\
\dot{0} \\
\dot{0} \\
H \\
\dot{0} \\
\dot{0} \\
\dot{v}\end{array}$ & 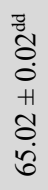 \\
\hline
\end{tabular}


Table 3. Continued...

\begin{tabular}{|c|c|c|c|c|c|c|c|c|c|c|c|c|c|c|c|c|c|c|c|c|}
\hline \multirow{2}{*}{ 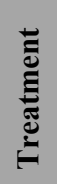 } & \multicolumn{4}{|c|}{$\begin{array}{c}\text { Total phenolic } \\
\text { compounds } \\
(\mathrm{mg} / 100 \mathrm{ml})\end{array}$} & \multicolumn{4}{|c|}{$\begin{array}{c}\text { Antioxidant activity } \\
\text { (\%) }\end{array}$} & \multicolumn{4}{|c|}{$\begin{array}{l}\text { Tannin content } \\
(\mathrm{mg} / \mathbf{1 0 0} \mathrm{ml})\end{array}$} & \multicolumn{4}{|c|}{ Reducing power $(\%)$} & \multicolumn{4}{|c|}{ Metal chelation (\%) } \\
\hline & $\mathbf{0}$ & 15 & 30 & 45 & $\mathbf{0}$ & 15 & 30 & 45 & $\mathbf{0}$ & 15 & 30 & 45 & $\mathbf{0}$ & 15 & 30 & 45 & $\mathbf{0}$ & 15 & 30 & 45 \\
\hline T5 & $\begin{array}{l}\stackrel{\Xi}{0} \\
\stackrel{0}{0} \\
\dot{0} \\
H \\
\stackrel{8}{0} \\
\dot{0}\end{array}$ & $\begin{array}{l}\tilde{\Xi} \\
\stackrel{0}{0} \\
\dot{0} \\
H \\
\text { H } \\
\stackrel{े}{े}\end{array}$ & 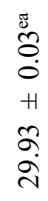 & 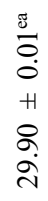 & $\begin{array}{l}\stackrel{\Xi}{\Xi} \\
\stackrel{0}{0} \\
\dot{0} \\
+ \\
\infty \\
m \\
\stackrel{0}{0}\end{array}$ & 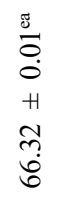 & $\begin{array}{l}0 \\
\tilde{0} \\
0 \\
0 \\
H \\
0 \\
0 \\
0 \\
0\end{array}$ & $\begin{array}{l}\stackrel{8}{0} \\
0 \\
0 \\
+ \\
+ \\
\stackrel{0}{0} \\
\stackrel{0}{0}\end{array}$ & 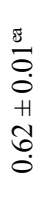 & 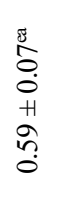 & $\begin{array}{l}\text { 總 } \\
0 \\
0 \\
+1 \\
\infty \\
0 \\
0\end{array}$ & 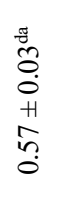 & 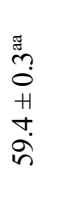 & 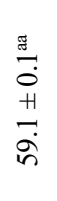 & $\begin{array}{l}\text { च̃ } \\
\text { o } \\
\text { H } \\
\infty \\
\infty \\
\infty \\
\infty\end{array}$ & $\begin{array}{l}\dot{y} \\
i \\
0 \\
+1 \\
+ \\
+ \\
\infty \\
i\end{array}$ & 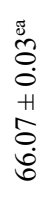 & $\begin{array}{l}\stackrel{\Xi}{J} \\
\dot{0} \\
\dot{0} \\
+1 \\
\dot{0} \\
\dot{8}\end{array}$ & 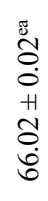 & $\begin{array}{l}\stackrel{0}{0} \\
0 \\
0 \\
+ \\
+1 \\
8 \\
\dot{8} \\
0\end{array}$ \\
\hline T6 & $\begin{array}{l}\stackrel{\varpi}{0} \\
\stackrel{0}{0} \\
H \\
\text { H } \\
\frac{0}{m}\end{array}$ & 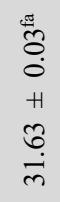 & 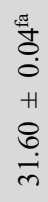 & 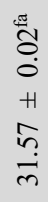 & 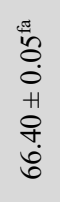 & 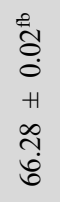 & 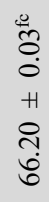 & 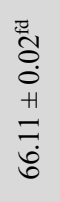 & 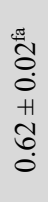 & $\begin{array}{l}\frac{\pi}{0} \\
0 \\
0 \\
+1 \\
\vdots \\
0 \\
0\end{array}$ & 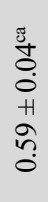 & $\begin{array}{l}\stackrel{5}{5} \\
0 \\
0 \\
+ \\
+1 \\
\infty \\
0 \\
0\end{array}$ & 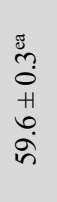 & 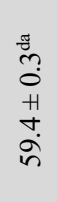 & 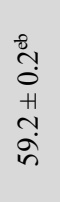 & 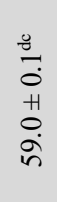 & 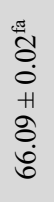 & 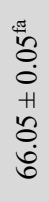 & 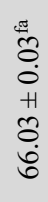 & $\begin{array}{l}2 \\
0 \\
0 \\
+ \\
H \\
0 \\
0 \\
0\end{array}$ \\
\hline $\mathrm{T} 7$ & 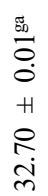 & 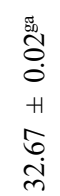 & 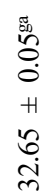 & 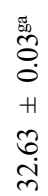 & 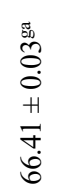 & 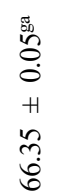 & $\begin{array}{l}\text { on } \\
0 \\
0 \\
0 \\
H \\
\text { H } \\
0 \\
0 \\
0 \\
0\end{array}$ & 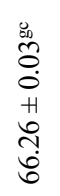 & $\begin{array}{l}\text { 范 } \\
0 \\
0 \\
0 \\
+1 \\
0\end{array}$ & 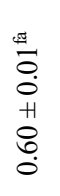 & 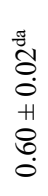 & 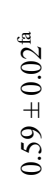 & $\begin{array}{l}\stackrel{\Xi}{H} \\
\overrightarrow{0} \\
+1 \\
\dot{0} \\
\infty \\
\infty\end{array}$ & 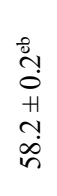 & $\begin{array}{l}0 \\
0 \\
0 \\
+1 \\
0 \\
\infty \\
\infty\end{array}$ & $\begin{array}{l}\vec{\Xi} \\
\stackrel{0}{0} \\
+1 \\
\text { aे } \\
\text { in }\end{array}$ & $\begin{array}{l}\text { 品 } \\
\stackrel{0}{0} \\
\dot{0} \\
+1 \\
\dot{0} \\
\dot{\sigma}\end{array}$ & $\begin{array}{l}\stackrel{8}{0} \\
0 \\
0 \\
0 \\
+1 \\
0 \\
0 \\
0 \\
0\end{array}$ & 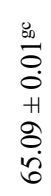 & 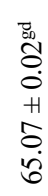 \\
\hline
\end{tabular}

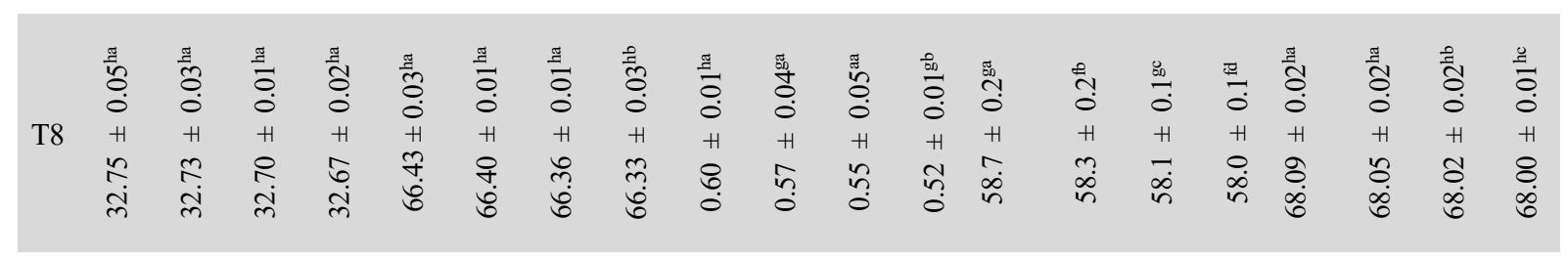

\begin{tabular}{|c|c|c|c|c|c|c|c|c|c|c|c|c|c|c|c|c|c|c|c|}
\hline \multirow{3}{*}{ T9 } & $\stackrel{\frac{\pi}{3}}{\circ}$ & $\begin{array}{l}\stackrel{a}{\widetilde{\Xi}} \\
\stackrel{0}{0}\end{array}$ & 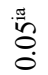 & $\begin{array}{l}\stackrel{\Omega}{\pi} \\
0 \\
0\end{array}$ & סֶ: & $\begin{array}{l}\stackrel{.}{0} \\
0 \\
0\end{array}$ & ڤัँ & $\frac{0}{\tilde{c}}$ & 孚 & $\stackrel{g}{\vec{J}}$ & 芯 & $\stackrel{\Xi}{0}$ & $\stackrel{g}{m}$ & 骂 & $\stackrel{0}{\stackrel{0}{0}}$ & 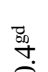 & कू & $\frac{\pi}{\sigma}$ & $\frac{\pi}{0}$ \\
\hline & H & $H$ & $H$ & $H$ & $H$ & $H$ & $H$ & $H$ & $H$ & $H$ & $H$ & $H$ & $H$ & $H$ & $H$ & $H$ & H & $H$ & H \\
\hline & $\begin{array}{l}\stackrel{\infty}{\infty} \\
\text { in }\end{array}$ & 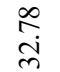 & $\frac{n}{\stackrel{n}{n}}$ & $\begin{array}{l}\underset{N}{\sim} \\
\text { ri }\end{array}$ & $\begin{array}{l}\text { ?f } \\
\text { do }\end{array}$ & $\begin{array}{l}\text { 웅 } \\
\text { \&̊ }\end{array}$ & $\begin{array}{l}\hat{n} \\
\text { bे }\end{array}$ & $\begin{array}{l}\text { గై } \\
\stackrel{8}{8}\end{array}$ & $\hat{n}$ & $\stackrel{t}{n}$ & กี & n̊. & $\begin{array}{l}a \\
i \\
i n\end{array}$ & $\begin{array}{l}n \\
\infty \\
n\end{array}$ & $\hat{i}$ & $\frac{n}{i n}$ & ڤి. & 뭉 & $\begin{array}{l}\dot{0} \\
\dot{0} \\
\dot{0}\end{array}$ \\
\hline
\end{tabular}

\begin{tabular}{|c|c|c|c|c|c|c|c|c|c|c|c|c|c|c|c|c|c|c|c|c|}
\hline T10 & 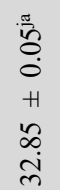 & 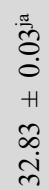 & 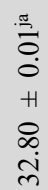 & 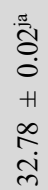 & $\begin{array}{l}\frac{\pi}{3} \\
0 \\
0 \\
+1 \\
0 \\
0 \\
0 \\
0\end{array}$ & 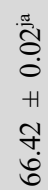 & 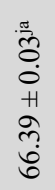 & 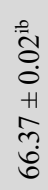 & $\begin{array}{l}\frac{\pi}{2} \\
\tilde{O} \\
0 \\
+ \\
\text { H } \\
\tilde{n} \\
0\end{array}$ & $\begin{array}{l}\frac{\pi}{0} \\
0 \\
0 \\
+1 \\
0 \\
0 \\
0\end{array}$ & \begin{tabular}{l}
$\stackrel{\Xi}{5}$ \\
$\stackrel{0}{0}$ \\
0 \\
+ \\
+ \\
\multirow{+}{+}{.}
\end{tabular} & 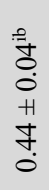 & $\begin{array}{l}\stackrel{\Xi}{0} \\
\dot{0} \\
+ \\
0 \\
\infty \\
\infty \\
\infty\end{array}$ & $\begin{array}{l}\frac{\pi}{3} \\
\dot{0} \\
+1 \\
\text { a. } \\
\text { in }\end{array}$ & $\begin{array}{l}\stackrel{0}{7} \\
\stackrel{0}{0} \\
+ \\
n \\
i \\
i n\end{array}$ & 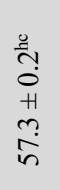 & 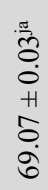 & $\begin{array}{l}\tilde{g} \\
\dot{0} \\
\dot{0} \\
+ \\
\dot{0} \\
\dot{0}\end{array}$ & $\begin{array}{l}\frac{\pi}{\tilde{\sigma}} \\
0 \\
0 \\
H \\
\tilde{0} \\
\dot{0}\end{array}$ & $\begin{array}{l}\stackrel{\circ}{0} \\
0 \\
0 \\
\text { H } \\
0 \\
0 \\
\dot{0}\end{array}$ \\
\hline
\end{tabular}

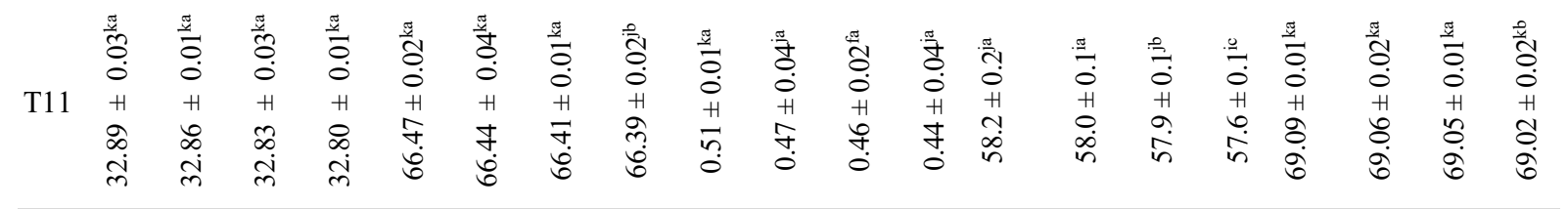

\begin{tabular}{|c|c|c|c|c|c|c|c|c|c|c|c|c|c|c|c|c|c|c|}
\hline T12 & 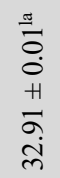 & $\begin{array}{l}\frac{\Omega}{0} \\
0 \\
\text { H } \\
\text { मे } \\
\text { के } \\
\text { के }\end{array}$ & $\begin{array}{l}\frac{\pi}{0} \\
0 \\
0 \\
H \\
\text { H } \\
\infty \\
i \\
\text { त. }\end{array}$ & 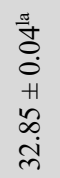 & 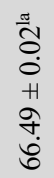 & 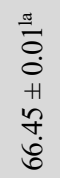 & $\begin{array}{l}\varrho \\
0 \\
0 \\
0 \\
+1 \\
\vec{f} \\
\dot{0}\end{array}$ & $\begin{array}{l}\frac{0}{0} \\
0 \\
0 \\
H \\
\infty \\
\infty \\
0 \\
0 \\
0\end{array}$ & $\begin{array}{l}\frac{\pi}{0} \\
0 \\
0 \\
+1 \\
0 \\
0 \\
0\end{array}$ & $\begin{array}{l}\text { 离 } \\
\text { ठ̣ } \\
\dot{0} \\
\text { H } \\
\text { f } \\
\dot{0}\end{array}$ & 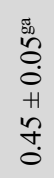 & 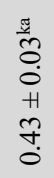 & 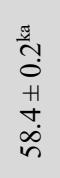 & 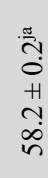 & $\begin{array}{l}\vec{\theta} \\
\dot{0} \\
H \\
0 \\
0 \\
\infty \\
\infty\end{array}$ & & & 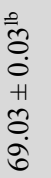 \\
\hline
\end{tabular}

*Mean $\pm \mathrm{SD}(\mathrm{n}=3) ; * *$ Different superscripts in the same column indicate a significant difference $(\mathrm{p}<0.05)$; ***Different superscripts in the same row indicate a significant difference $(\mathrm{p}<0.05)$. T1:70 ${ }^{\circ} \mathrm{C}, 10 \mathrm{~min}, 200 \mathrm{ppm} ; \mathrm{T} 2: 70{ }^{\circ} \mathrm{C}, 10 \mathrm{~min}, 300 \mathrm{ppm} ; \mathrm{T} 3: 70{ }^{\circ} \mathrm{C}, 10 \mathrm{~min}, 400 \mathrm{ppm}$; $\mathrm{T} 4: 70{ }^{\circ} \mathrm{C}, 20 \mathrm{~min}, 200 \mathrm{ppm} ; \mathrm{T} 5: 70{ }^{\circ} \mathrm{C}, 20 \mathrm{~min}, 300 \mathrm{ppm} ; \mathrm{T} 6: 70{ }^{\circ} \mathrm{C}, 20 \mathrm{~min}, 400 \mathrm{ppm} ; \mathrm{T} 7: 80{ }^{\circ} \mathrm{C}, 10 \mathrm{~min}, 200 \mathrm{ppm} ; \mathrm{T} 8: 80{ }^{\circ} \mathrm{C}, 10 \mathrm{~min}, 300 \mathrm{ppm}$; $\mathrm{T} 9: 80^{\circ} \mathrm{C}, 10 \mathrm{~min}, \quad 400 \mathrm{ppm} ; \mathrm{T} 10: 80^{\circ} \mathrm{C}, 20 \mathrm{~min}, 200 \mathrm{ppm} ; \mathrm{T} 11: 80^{\circ} \mathrm{C}, 20 \mathrm{~min}, 300 \mathrm{ppm} ; \mathrm{T} 12: 80{ }^{\circ} \mathrm{C}, 20 \mathrm{~min}, 400 \mathrm{ppm}$. 


\subsection{The effects of the variables on the microbial counts}

The TPC of the juice varied from 1.950 (T1) to 1.650 (T12) on day 0 of storage due to the different treatments (Table 4). The decreased count in T12 might be due to the longer pasteurization time and greater KMS concentration, since a longer heating time and more KMS can kill more microorganisms since bacteria, yeasts and moulds are heat sensitive and are easily destroyed by heat treatment. Similar findings were reported by Sankhla et al. (2012) for sugarcane juice. An increase in TPC was observed with an increase in storage period and similar findings were reported by Chauhan et al. (2002) and Sakhale et al. (2012). The MIC varied from 3.2 (T1) to 2.2 (T12) on day 0 of storage and increased with increase in storage time.

Table 4. The effect of the variables on the microbial count.

\begin{tabular}{|c|c|c|c|c|}
\hline \multirow{2}{*}{ Treatments } & \multicolumn{2}{|c|}{ TPC } & \multicolumn{2}{|c|}{ MIC } \\
\hline & $\mathbf{0}$ & 45 & $\mathbf{0}$ & 45 \\
\hline $\mathrm{T} 1$ & $1.950 \pm 0.001^{*} \mathrm{a}^{* *} \mathrm{a}^{* * *}$ & $2.079 \pm 0.003^{\mathrm{ab}}$ & $3.2 \pm 0.2^{\text {aa }}$ & $3.4 \pm 0.4^{\mathrm{aa}}$ \\
\hline $\mathrm{T} 2$ & $1.880 \pm 0.001^{\mathrm{ba}}$ & $2.072 \pm 0.002^{\mathrm{ab}}$ & $2.5 \pm 0.5^{\mathrm{ba}}$ & $2.7 \pm 0.1^{\text {ba }}$ \\
\hline $\mathrm{T} 3$ & $1.830 \pm 0.001^{\mathrm{ca}}$ & $1.973 \pm 0.003^{\mathrm{bb}}$ & $2.4 \pm 0.4^{\mathrm{ca}}$ & $2.5 \pm 0.5^{\mathrm{ca}}$ \\
\hline $\mathrm{T} 4$ & $1.820 \pm 0.001^{\mathrm{da}}$ & $1.860 \pm 0.003^{\mathrm{ca}}$ & $2.4 \pm 0.2^{\mathrm{ad}}$ & $2.6 \pm 0.1^{\mathrm{da}}$ \\
\hline T5 & $1.800 \pm 0.004^{\mathrm{ea}}$ & $1.840 \pm 0.002^{\mathrm{da}}$ & $2.3 \pm 0.3^{\mathrm{ea}}$ & $2.4 \pm 0.1^{\mathrm{ea}}$ \\
\hline T6 & $1.780 \pm 0.002^{\mathrm{fa}}$ & $1.800 \pm 0.004^{\mathrm{ea}}$ & $2.2 \pm 0.2^{\mathrm{fa}}$ & $2.5 \pm 0.5^{\mathrm{fa}}$ \\
\hline $\mathrm{T} 7$ & $1.750 \pm 0.001^{\mathrm{ga}}$ & $1.810 \pm 0.002^{\mathrm{fb}}$ & $2.7 \pm 0.2^{\text {aa }}$ & $3.1 \pm 0.1^{\text {aa }}$ \\
\hline $\mathrm{T} 8$ & $1.790 \pm 0.003^{\text {ha }}$ & $1.857 \pm 0.001^{\mathrm{gb}}$ & $2.5 \pm 0.4^{\mathrm{aa}}$ & $2.7 \pm 0.4^{\mathrm{ga}}$ \\
\hline T9 & $1.760 \pm 0.001^{\mathrm{ia}}$ & $1.845 \pm 0.005^{\mathrm{hb}}$ & $2.4 \pm 0.1^{\text {aa }}$ & $2.8 \pm 0.1^{\text {aa }}$ \\
\hline $\mathrm{T} 10$ & $1.700 \pm 0.001^{\mathrm{ja}}$ & $1.780 \pm 0.003^{\mathrm{ib}}$ & $2.7 \pm 0.2^{\text {aa }}$ & $3.0 \pm 0.1^{\text {aa }}$ \\
\hline T11 & $1.690 \pm 0.002^{\mathrm{ka}}$ & $1.693 \pm 0.003^{\mathrm{ja}}$ & $2.2 \pm 0.1^{\mathrm{ga}}$ & $2.5 \pm 0.1^{\text {ha }}$ \\
\hline $\mathrm{T} 12$ & $1.650 \pm 0.002^{\mathrm{la}}$ & $1.653 \pm 0.003^{\mathrm{ka}}$ & $2.2 \pm 0.2^{\text {ha }}$ & $2.4 \pm 0.4^{\text {ia }}$ \\
\hline
\end{tabular}

*Mean $\pm \mathrm{SD}(\mathrm{n}=3) ; * *$ Different superscripts in the same column indicate a significant difference $(\mathrm{p}<0.05) ; * * *$ Different superscripts in the same row indicate a significant difference $(\mathrm{p}<0.05)$. T1:70 ${ }^{\circ} \mathrm{C}, 10 \mathrm{~min}, 200 \mathrm{ppm} ; \mathrm{T} 2: 70{ }^{\circ} \mathrm{C}, 10 \mathrm{~min}, 300 \mathrm{ppm} ; \mathrm{T} 3: 70{ }^{\circ} \mathrm{C}, 10 \mathrm{~min}, 400 \mathrm{ppm}$; $\mathrm{T} 4: 70{ }^{\circ} \mathrm{C}, 20 \mathrm{~min}, 200 \mathrm{ppm} ; \mathrm{T} 5: 70{ }^{\circ} \mathrm{C}, 20 \mathrm{~min}, 300 \mathrm{ppm} ; \mathrm{T} 6: 70{ }^{\circ} \mathrm{C}, 20 \mathrm{~min}, 400 \mathrm{ppm} ; \mathrm{T} 7: 80{ }^{\circ} \mathrm{C}, 10 \mathrm{~min}, 200 \mathrm{ppm} ; \mathrm{T} 8: 80^{\circ} \mathrm{C}, 10 \mathrm{~min}, 300 \mathrm{ppm}$; $\mathrm{T} 9: 80^{\circ} \mathrm{C}, 10 \mathrm{~min}, 400 \mathrm{ppm}$; $\mathrm{T} 10: 80^{\circ} \mathrm{C}, 20 \mathrm{~min}, 200 \mathrm{ppm}$; $\mathrm{T} 11: 80^{\circ} \mathrm{C}, 20 \mathrm{~min}, 300 \mathrm{ppm}$; T12:80 ${ }^{\circ} \mathrm{C}, 20 \mathrm{~min}, 400 \mathrm{ppm}$.

\subsection{Cluster analysis of the different variables in the spiced chayote juice during storage}

The data obtained from the physicochemical analysis of the blended chayote juice during storage was analysed using a cluster analysis with a rescaled distance cluster analysis as shown in Figure 1. It is evident from the figure that two major clusters had been formed and that clustering was on the basis of temperature. The first cluster comprised the blended chayote juices prepared at $70^{\circ} \mathrm{C}$, whereas the second cluster comprised the spiced chayote juices prepared at $80^{\circ} \mathrm{C}$, which indicates that of all the variables under study, the temperature had the most significant effect on the physicochemical and sensory characteristics of the spiced chayote juice, as compared to the time and KMS concentration, which failed to fall into separate and respective clusters.

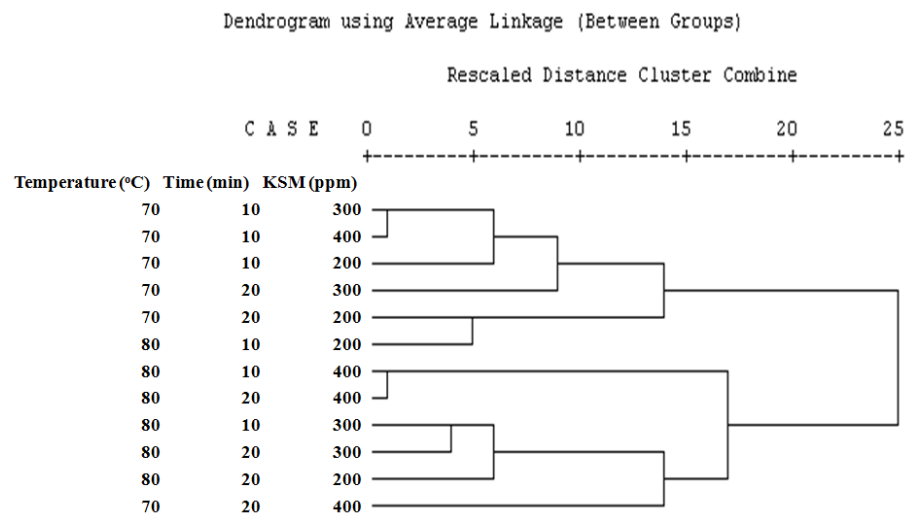

Figure 1. Cluster analysis of different variables selected for the storage of spiced chayote juice. 


\section{Conclusion}

The preservation of blended chayote juice without the addition of any chemical preservative or pasteurization is not possible due to its high nutritional content. The results of the present study showed that the different variables studied (temperature, time, preservatives and storage durations) caused significant effects on the quality attributes of the blended chayote juice, with increases in temperature, time and KMS concentration causing small but significant decreases in the sensory and phytochemical parameters. However, in real terms the decreases were low, which indicates that even lower concentrations of these hurdles would be effective. In the case of storage time, the same trend was observed in a negative manner, but the blended chayote juice can be successfully preserved for up to 45 days under refrigerated storage conditions, based on the different quality attributes. Thus, it was concluded that the blended chayote juice could be preserved using hurdle technology, pasteurizing at $70{ }^{\circ} \mathrm{C}$ for $10 \mathrm{~min}$ followed by the addition of $200 \mathrm{ppm} \mathrm{KMS,} \mathrm{and} \mathrm{stored} \mathrm{for} \mathrm{forty-five} \mathrm{days} \mathrm{under} \mathrm{refrigeration.}$

\section{Acknowledgements}

The authors are grateful to the Lovely Professional University for providing the infrastructure and financial support for this study.

\section{References}

Aguiñiga-Sánchez, I., Soto-Hernández, M., Cadena-Iñiguez, J., Ruíz-Posadas, Ldel. M., Cadena-Zamudio, J. D., GonzálezUgarte, A. K., Steider, B. W., \& Santiago-Osorio, E. (2015). Fruit Extract from A Sechiumedule Hybrid Induce Apoptosis in Leukaemic Cell Lines but not in Normal Cells. Nutrition and Cancer, 67(2), 250-257. PMid:25611564. http://dx.doi.org/10.1080/01635581.2015.989370

Álvarez-Ordóñez, A., Fernández, A., Bernardo, A., \& López, M. (2009). Comparison of acids on the induction of an acid tolerance response in Salmonella typhimurium, consequences for food safety. Meat Science, 81(1), 65-70. PMid:22063963. http://dx.doi.org/10.1016/j.meatsci.2008.06.019

Amerine, M. A., Pangborn, R. M., \& Roessler, E. B. (1965). Principles of sensory evaluation of food. New York: Academic Press. Ashurst, P. R., \& Hargitt, R. (2009). Soft drink and fruit juice problems solved. Oxford: CRC Press, Woodhead Publishing. Association of Official Analytical Chemistry - AOAC. (1984). Official Methods of Analysis of the Association of Official Analytical Chemists (14th ed.). Arlington: AOAC.

Bhattacherjee, A. K., Tandon, D. K., Dikshit, A., \& Kumar, S. (2011). Effect of pasteurization temperature on quality of aonla juice during storage. Journal of Food Science and Technology, 48(3), 269-273. PMid:23572745. http://dx.doi.org/10.1007/s13197-010-0171-5

Brand-Williams, W., Cuvelier, M. E., \& Berset, C. (1995). Use of a free radical method to evaluate antioxidant activity. FLWT Food Science and Technology, 28(1), 25-30. https://doi.org/10.1016/S0023-6438(95)80008-5.

Chakrabortya, I., \& Athmaselvi, K. A. (2014). Changes in physicochemical properties of guava juice during ohmic heating. Journal of Ready to Eat Food, 1(4), 152-157.

Chauhan, O. P., Singh, D., Tyagi, S. M., \& Balyan, D. K. (2002). Studies on preservation of sugarcane juice. International Journal of Food Properties, 5(1), 217-229. http://dx.doi.org/10.1081/JFP-120015603

Dinis, T. C., Madeira, V. M., \& Almeida, L. M. (1994). Action of phenolic derivatives (acetaminophen, salicylate, and 5aminosalicylate) as inhibitors of membrane lipid peroxidation and as peroxyl radical scavengers. Archives of Biochemistry and Biophysics, 315(1), 161-169. PMid:7979394. http://dx.doi.org/10.1006/abbi.1994.1485

Durrani, Y., Ayub, M., Muhammad, A., \& Ali, A. (2010). Physicochemical response of apple pulp to chemical preservatives and antioxidant during storage. International Journal of Food Safety, 12, 20-28.

Firdous, S., Sravanthi, K., Debnath, R., \& Neeraja, K. A. (2012). Protective effect of ethanolic extract and its ethylacetate and nbutanol fractions of Sechiumedule fruits against carbon tetrachloride induced hepatic injury in rats. International Journal of Pharmacy and Pharmaceutical Sciences, 4(1), 354-359.

Frazier, W. C., \& Westhoff, D. C. (1988). Food microbiology (3rd ed., pp. 111-112). New York: McGraw-Hill Publishing.

Gao, J., \& Rupasinghe, H. V. (2012). Nutritional, physicochemical and microbial quality of ultrasound-treated apple-carrot juice blends. Food and Nutrition Sciences, 3(02), 212-218. http://dx.doi.org/10.4236/fns.2012.32031

Hashem, H. A., Sharaf, A. M., Amira, S. A., \& Ibrahim, G. E. (2014). Changes in physico-chemical quality and volatile compounds of orange-carrot juice blends during storage. Food Science and Quality Management, 33, 21-35.

Hernandez-Uribe, J. P., Agama-Acevedo, E., Gonzalez-Soto, R. A., Bello-Pérez, L. A., \& Vargas-Torres, A. (2011). Isolation and characterization of Mexican chayote tuber (Sechiumedule Sw.) starch. Stärke, 63(1), 32-41.

http://dx.doi.org/10.1002/star.201000078 
Hussain, I., Zeb, A., \& Ayub, M. (2011). Evaluation of apple and apricot blend juice preserved with sodium benzoate at refrigeration temperature. World Journal of Agricultural Sciences, 7(2), 136-142.

Ibrahim, M. A. (2016). Effect of different storage condition on $\mathrm{pH}$ and vitamin $\mathrm{C}$ content in some selected fruit juices (pineapple, pawpaw and watermelon). International Journal of Biochemistry Research and Review, 2, 1-5. http://dx.doi.org/10.9734/IJBCRR/2016/23462.

Jamil, M., UI Haq, I., Mirza, B., \& Qayyum, M. (2012). Isolation of antibacterial compounds from Quercusdilatata L. through bioassay guided fractionation. Annals of Clinical Microbiology and Antimicrobials, 11(1), 11. PMid:22554280. http://dx.doi.org/10.1186/1476-0711-11-11

Joshi, V. K. (2006). Sensory science: principles and applications in evaluation of food. Udaipur, India: Agro-Tech Publishers.

Kapasakalidis, P. G., Rastall, R. A., \& Gordon, M. H. (2006). Extraction of polyphenols from processed black currant (Ribesnigrum L.) residues. Journal of Agricultural and Food Chemistry, 54(11), 4016-4021. PMid:16719528. http://dx.doi.org/10.1021/jf052999l

Kayshar, M. S., Rahman, A., Sultana, M. S., Fatema, K., \& Kabir, M. F. (2014). Formulation, preparation and storage potentiality study of mixed squashes from papaya, banana and carrot in Bangladesh. Journal of Agriculture and Veterinary Science, 7(2), 47-51. http://dx.doi.org/10.9790/2380-07234751

Kregiel, D. (2015). Health safety of soft drinks: contents, containers, and microorganisms. BioMed Research International, 2015, 128697. PMid:25695045. http://dx.doi.org/10.1155/2015/128697

Kunitake, M., Ditchfield, C., Silva, C., \& Petrus, R. (2014). Effect of pasteurization temperature on stability of an acidified sugarcane juice beverage. Ciência e Agrotecnologia, 38(6), 554-561. http://dx.doi.org/10.1590/S1413-70542014000600004

Lanjhiyana, R., Sharma, P. K., \& Shukla, N. (2010). Studies on effect of chemical preservatives on physico-chemical changes of beverages in lime and ginger juice with their combinations. Journal of Horticultural Sciences, 5(2), 151-154.

Leistner, L., \& Gould, G. W. (2012). The hurdle concept. In L. Leistner, \& G. W. Gould. Hurdle technologies: combination treatments for food stability, safety and quality. (chap. 2, pp. 17-27). USA: Springer Science \& Business Media. https://doi.org/10.1007/978-1-4615-0743-7.

Lombardo-Earl, G., Roman-Ramos, R., Zamilpa, A., Herrera-Ruiz, M., Rosas-Salgado, G., Tortoriello, J., \& Jiménez-Ferrer, E. (2014). Extracts and fractions from edible roots of Sechiumedule (Jacq.) Sw. with antihypertensive activity. Evidence-Based Complementary and Alternative Medicine, 2014, 1-9. PMid:24812568. http://dx.doi.org/10.1155/2014/594326

Madan, S., \& Dhawan, S. S. (2005). Studies on the development of bottled carrot slices. Beverage Food World, 32(5), 15-19.

Maity, S., Firdous, S. M., \& Debnath, R. (2013). Evaluation of antidiabetic activity of ethanolic extract of Sechiumedule fruits in alloxan-induced diabetic rats. World Journal of Pharmacy and Pharmaceutical Sciences, 2(5), 3612-3621.

Mgaya-Kilima, B., Remberg, S. F., Chove, B. E., \& Wicklund, T. (2014). Influence of storage temperature and time on the physicochemical and bioactive properties of roselle-fruit juice blends in plastic bottle. Food Science \& Nutrition, 2(2), 181-191. PMid:24804077. http://dx.doi.org/10.1002/fsn3.97

Mishra, L. K., \& Das, P. (2015). Nutritional evaluation of squash (Sechium Edule) germplasms collected from garo hills of meghalaya-north East India. International Journal of Agriculture Environment and Biotechnology, 8(4), 971. http://dx.doi.org/10.5958/2230-732X.2015.00111.4.

Mumtaz, S. M. F., Paul, S., \& Bag, A. K. (2012). Effect of sechiumedule on chemical induced kidney damage in experimental animals. Bangladesh Journal of Pharmacology, 8(1), 28-35. http://dx.doi.org/10.3329/bjp.v8i1.12982

Oszmianski, J., \& Wojdylo, A. (2009). Comparative study of phenolic content and antioxidant activity of strawberry puree, clear, and cloudy juices. European Food Research and Technology, 228(4), 623-631. http://dx.doi.org/10.1007/s00217-008-0971-2

Oyaizu, M. (1986). Studies on products of browning reaction. Eiyogaku Zasshi, 44(6), 307-315. http://dx.doi.org/10.5264/eiyogakuzashi.44.307

Pareek, S., Paliwal, R., \& Mukherjee, S. (2015). Effect of juice extraction methods, potassium metabisulphite concentration and storage temperature on the extent of degradation and reactivity of chemical constituents in mandarin (Citrus reticulata Blanco) juice. Journal of Food Agriculture and Environment, 13(2), 39-44.

Profir, A., \& Vizireanu, C. (2013). Effect of the preservation processes on the storage stability of juice made from carrot, celery and beetroot. Journal of Agroalimentary Processes and Technologies, 19(1), 99-104.

Ranganna, S. (1986). Proximate constituents. In S. Ranganna. Handbook of analysis and quality control for fruit and vegetable products (2nd ed., pp. i-30). New Delhi: McGraw-Hill Publishing Company Ltd..

Rawat, K., \& Pokhriyal, S. (2014). Preservation of sugarcane juice using hurdle technology. International Journal of Scientific Engineering and Technology, 3(12), 1455-1458. http://dx.doi.org/10.1007/s12355-011-0127-8.

Riaz, R. A., Ali, A., \& Saleem, M. (1989). Studies on the preparation and storage stability of comminuted kinow fruit beverage bees. Pakistan Journal of Scientific and Industrial Research, 32, 574-578.

Sadasivam, S., \& Manickam, A. C. (1992). Biochemical methods. New Delhi, India: New Age International Ltd.

Sakhale, B. K., Pawar, V. N., \& Ranveer, R. C. (2012). Studies on the development and storage of whey based RTS beverage from mango cv. Kesar. Journal of Food Processing \& Technology, 3(3), 148. http://dx.doi.org/10.4172/2157-7110.1000148.

Sangma, C., Kumar, V., Gat, Y., Kaushal, M., Suri, S., \& Panghal, A. (2018). Optimization of preparation process for a blended beverage developed from chayote, sugarcane, and mint and coriander extract. International Journal of Vegetable Science, 24(5), 1-13. $h$ ttp://dx.doi.org/10.1080/19315260.2018.1434262. 
Sankhla, S., Chaturvedi, A., Kuna, A., \& Dhanlakshmi, K. (2012). Preservation of sugarcane juice using hurdle technology. Sugar Tech, 14(1), 26-39. http://dx.doi.org/10.1007/s12355-011-0127-8

Talasila, U., Vechalapu, R. R., \& Shaik, K. B. (2012). Storage stability of cashew apple juice-use of chemical preservatives. Journal of Food Technology, 10(4), 117-123. http://dx.doi.org/10.3923/jftech.2012.117.123.

Wisal, S., Ullah, J., Zeb, A., \& Khan, M. Z. (2013). Effect of refrigeration temperature, sugar concentrations and different chemicals preservatives on the storage stability of strawberry juice. IACSIT International Journal of Engineering and Technology, 13(02), 160-168. 